Article

\title{
Repurposing Auranofin and Evaluation of a New Gold(I) Compound for the Search of Treatment of Human and Cattle Parasitic Diseases: From Protozoa to Helminth Infections
}

\author{
Liwen Feng ${ }^{1,+}{ }^{-}$, Sébastien Pomel ${ }^{2}{ }^{\oplus}$, Perle Latre de Late ${ }^{3}$, Alexandre Taravaud ${ }^{2}$, \\ Philippe M. Loiseau ${ }^{2}{ }^{(0}$, Louis Maes $\left.{ }^{4}{ }^{(}\right)$, Fidelis Cho-Ngwa ${ }^{5}$, Christina A. Bulman ${ }^{6}$, \\ Chelsea Fischer ${ }^{6}$, Judy A. Sakanari ${ }^{6}$, Peter D. Ziniel ${ }^{7}$, David L. Williams ${ }^{7, *}$ \\ and Elisabeth Davioud-Charvet $1, *$ (i)
}

1 UMR 7042 CNRS-Université de Strasbourg-Université Haute-Alsace, Laboratoire d'Innovation Moléculaire et Applications (LIMA), Bioorganic and Medicinal Chemistry Team, European School of Chemistry, Polymers and Materials (ECPM), 25, rue Becquerel, F-67087 Strasbourg, France; liwen.feng@etu.unistra.fr BioCIS, Faculty of Pharmacy, Université Paris-Saclay, CNRS, 92290 Châtenay-Malabry, France; sebastien.pomel@u-psud.fr (S.P.); alexandre.taravaud@u-psud.fr (A.T.); philippe.loiseau@u-psud.fr (P.M.L.)

3 INSERM U1016, CNRS UMR 8104, Laboratoire de Biologie Cellulaire Comparative des Apicomplexes, Cochin Institute, Faculté de Medecine, Université Paris Descartes, Sorbonne Paris Cité, 75014 Paris, France; P.LatredeLate@cgiar.org

4 Laboratory of Microbiology, Parasitology and Hygiene (LMPH), Faculty of Pharmaceutical, Biomedical and Veterinary Sciences, University of Antwerp, Universiteitsplein 1, B-2610 Antwerp, Belgium; louis.maes@uantwerpen.be

5 Biotechnology Unit, Faculty of Science, University of Buea, Buea P.O. Box 63, Cameroon; chongwa_ub@yahoo.co.uk

6 Department of Pharmaceutical Chemistry, University of California, San Francisco, CA 94158, USA; Christina.Bulman@ucsf.edu (C.A.B.); chelsea.fischer811@gmail.com (C.F.); Judy.Sakanari@ucsf.edu (J.A.S.)

7 Department of Microbial Pathogens and Immunity, Rush University Medical Center, Chicago, IL 60612, USA; petezii2001@yahoo.com

* Correspondence: David_Williams@rush.edu (D.L.W.); elisabeth.davioud@unistra.fr (E.D.-C.)

+ Present Address: School of Pharmaceutical Sciences (Shenzhen), Sun-Yat Sen University, Guangzhou 510275, China; fenglw5@mail.sysu.edu.cn.

Academic Editor: Thomas J. Schmidt

Received: 3 September 2020; Accepted: 27 October 2020; Published: 1 November 2020

\begin{abstract}
Neglected parasitic diseases remain a major public health issue worldwide, especially in tropical and subtropical areas. Human parasite diversity is very large, ranging from protozoa to worms. In most cases, more effective and new drugs are urgently needed. Previous studies indicated that the gold(I) drug auranofin (Ridaura ${ }^{\circledR}$ ) is effective against several parasites. Among new gold(I) complexes, the phosphole-containing gold(I) complex \{1-phenyl-2,5-di(2-pyridyl)phosphole\} AuCl (abbreviated as GoPI) is an irreversible inhibitor of both purified human glutathione and thioredoxin reductases. GoPI-sugar is a novel 1-thio- $\beta$-D-glucopyranose 2,3,4,6-tetraacetato-S-derivative that is a chimera of the structures of GoPI and auranofin, designed to improve stability and bioavailability of GoPI. These metal-ligand complexes are of particular interest because of their combined abilities to irreversibly target the essential dithiol/selenol catalytic pair of selenium-dependent thioredoxin reductase activity, and to kill cells from breast and brain tumors. In this work, screening of various parasites-protozoans, trematodes, and nematodes-was undertaken to determine the in vitro killing activity of GoPI-sugar compared to auranofin. GoPI-sugar was found to efficiently kill intramacrophagic Leishmania donovani amastigotes and adult filarial and trematode worms.
\end{abstract}


Keywords: anticancer; anti-amoeba; anti-helminth; anti-leishmanial; antiparasitic; anti-trypanosomal; auranofin; glutathione; gold(I) complex; redox equilibrium; thioredoxin

\section{Introduction}

After alchemists discovered they could dissolve gold using aqua regia in the middle ages, gold compounds started to be used in medicinal treatments [1]. Robert Koch first observed the bacteriostatic activity of potassium gold cyanide $\mathrm{K}\left[\mathrm{Au}(\mathrm{CN})_{2}\right]$ in the $1890^{\prime}$ s, introducing gold therapies into modern medicine [2]. Jacques Forestier treated patients affected by rheumatoid arthritis (RA) with inorganic gold salts [3,4]. In the 1940's, the $\mathrm{Au}(\mathrm{I})$-phosphine auranofin $\left(\mathrm{Au}^{\mathrm{I}}\left(\mathrm{PEt}_{3}\right)\right.$ thioglucose, Figure 1$)$ used by oral administration was considered safer than the injectable inorganic gold salts, and was approved in 1985 by the USA Food and Drug Administration for RA therapy [5-7]. Recently, auranofin has been rediscovered as potential alternative treatments for other diseases, such as some cancers, inflammation, bacterial infections, HIV, neurodegenerative disorders and parasitic infections [8-10].

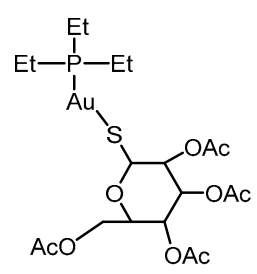

Auranofin
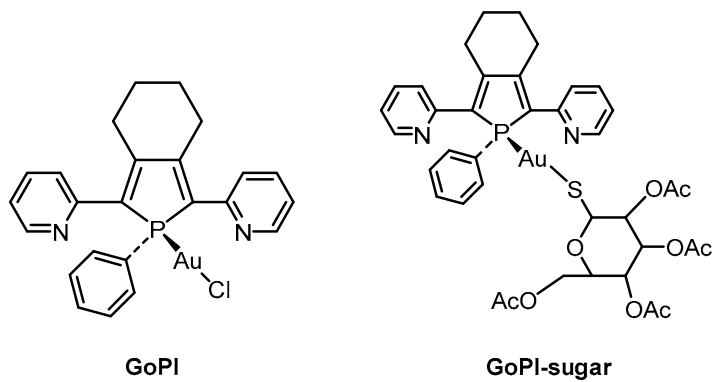

Figure 1. Structure of gold(I)-based complexes as inhibitors of human glutathione reductase, thioredoxin reductase and Schistosoma mansoni thioredoxin-glutathione reductase.

Due to its central role in cell metabolism, the thioredoxin (Trx) system is involved in many pathological conditions and provides potential therapeutic targets. Auranofin and aurothioglucose specifically inhibit human thioredoxin reductase (TrxR) with a Ki of $4 \mathrm{nM}$ [11]. Phospholes are phosphacyclopentadienes that have very limited aromatic character (for an example, see Figure 1), and a nucleophilic phosphorus atom. Our previous studies have found that novel gold phosphole complexes, 1-thio- $\beta$-D-glucopyranose 2,3,4,6-tetraacetato-S-Au\{1-phenyl-2,5-di(2-pyridyl)phosphole\} (GoPI-sugar) and its precursor GoPI \{1-phenyl-2,5-di(2-pyridyl)phosphole\} $\mathrm{AuCl}(\mathrm{GoPI})$, were potent inhibitors of human glutathione reductase (GR) [12,13] and TrxR [13-15]. GoPI-sugar was designed to improve the solubility, stability and bioavailability of GoPI.

The inhibition of reduction/oxidation enzymes containing sulfur or selenium within the active site, such as GR [12] and selenoCys-containing TrxRs [11,16-18], is one of the mechanisms of action of auranofin and most of the gold(I) complexes. Inhibition of these key NADPH-dependent disulfide reductases can affect the intracellular redox balance, leading to elevated intracellular oxidative stress levels and cellular apoptosis. Other mechanisms are likely to be involved in vivo, such as DNA binding, which at least partially may mediate anti-tumor properties by inducing antiproliferative effects $[13,15,19]$. This dual mode of action is expected to increase cytotoxicity towards rapidly dividing cells over-expressing disulfide reductases, such as cancer cells, memory T cells that harbor proviral HIV DNA, and a broad panel of parasites. Due to its central role in cell metabolism, the Trx system is involved in many pathological conditions and provides potential targets for novel therapeutic approaches. We have already identified several TrxR inhibitors that show growth-inhibitory properties against tumor cells [20-22] and parasites [23-25]. 
The mechanism of action of the anti-arthritic drug auranofin and GoPI-sugar may be similar: they likely lose both the thioglucose and the trialkylphosphine ligands, leading to final gold(I) protein thiol adducts similar to those arising from inorganic gold salts. This hypothesis, first proposed for auranofin [26], was later confirmed following the resolution of the 3D structure of human GR alkylated by GoPI [13] and Schistosoma mansoni thioredoxin glutathione reductase (TGR) with auranofin [27]. Both gold(I) chloro(triligand) phosphine were shown to be bioactivated by a process involving the transient displacement of the thiosugar moiety or the chlorine atom (in GoPI) by (redox) protein(s) or low molecular weight thiols before irreversibly binding to the disulfide reductase. Both leaving groups, the chlorine atom and the thiosugar part, are known to be displaced by cysteine and histidine residues of albumin or cyclophilin-3, respectively [28,29]. Following different reversible exchanges with thiol groups or proteins in the blood, these gold(I) complexes are known to bind (redox) protein(s) or low molecular weight thiols before irreversibly binding to the common final DNA target. The inhibition of human GR and TrxR, after stepwise ligand displacement resulted in a covalently bound gold atom between the two active site cysteines of hGR (S-Au-S coordination) [13].

Previous studies showed that auranofin can inhibit the growth and viability of various parasites: S. mansoni [24], Trypanosoma cruzi [30], Leishmania infantum [31], Plasmodium falciparum [32], Giardia lamblia [33], larval Echinococcus granulosus [34], Entamoeba histolytica [35], and adult filarial worms [36]. These interesting data prompted us to screen GoPI-sugar against various parasites to identify those most sensitive to killing. In this work, in vitro activities of auranofin and GoPIsugar were studied on a large panel of parasites, including S. mansoni, Brugia pahangi, Loa loa, Onchocerca ochengi, Trypanosoma brucei, T. cruzi, Leishmania infantum, and L. donovani, Theileria annulata, and Acanthamoeba castellanii.

\section{Results}

\subsection{Synthesis of GoPI-Sugar}

A multigram batch of GoPI-sugar was re-synthesized according to a reported five-step-long sequence (Scheme 1). The synthesis of the bis(2-pyridyl)phosphole ligand 4 started by a Sonogashira coupling reaction under classical conditions [37] from commercial octa-1,7-diyne $\mathbf{1}$ and 2-bromopyridine 2 leading to the diyne 3 in excellent yield. Then, diyne 3 was first oxidatively cyclized with zirconocene to give corresponding zirconacyclopentadiene, followed by the electrophilic $[\mathrm{ZrCp} 2] / \mathrm{PPhCl}_{2}$ substitution reaction [38]. This Fagan-Nugent-based route, which afforded a classical and efficient method for heterocycle synthesis, provided phosphole ligand 4 in moderate yields [39,40]. Furthermore, the resulting phosphole ligand 4 was extremely air- and moisture-sensitive, requiring utilization of the crude product directly in the next step of reaction without purification. Subsequently, the phosphole ligand was coordinated to the central metal gold with freshly prepared $\mathrm{AuCl}$ (tetrahydrothiophene) to yield GoPI (5) [12]. Finally, a classical nucleophilic substitution reaction was performed by deprotonated acetylthioglucose, leading to the air-stable GoPi-sugar (6) with high purity (>98\%, see Supplementary Materials) and in moderate yield [15]. Several batches of $300 \mathrm{mg}$ scale were produced for biological studies.

\subsection{Inhibitory Activities of Gold(I) Complexes against Members of the NADPH-Dependent Disulfide Reductase Family}

We have already reported that gold(I) complexes, such as GoPI and GoPI-sugar, act as potent irreversible inhibitors of human TrxR (Table 1) [13-15]. This study focused on comparing the inhibitory activity of GoPI-sugar versus auranofin against S. mansoni TGR and B. pahangi TrxR. GoPI-sugar was found to have low nM activity against these two enzymes, about 10 times that found with auranofin (Table 1). 

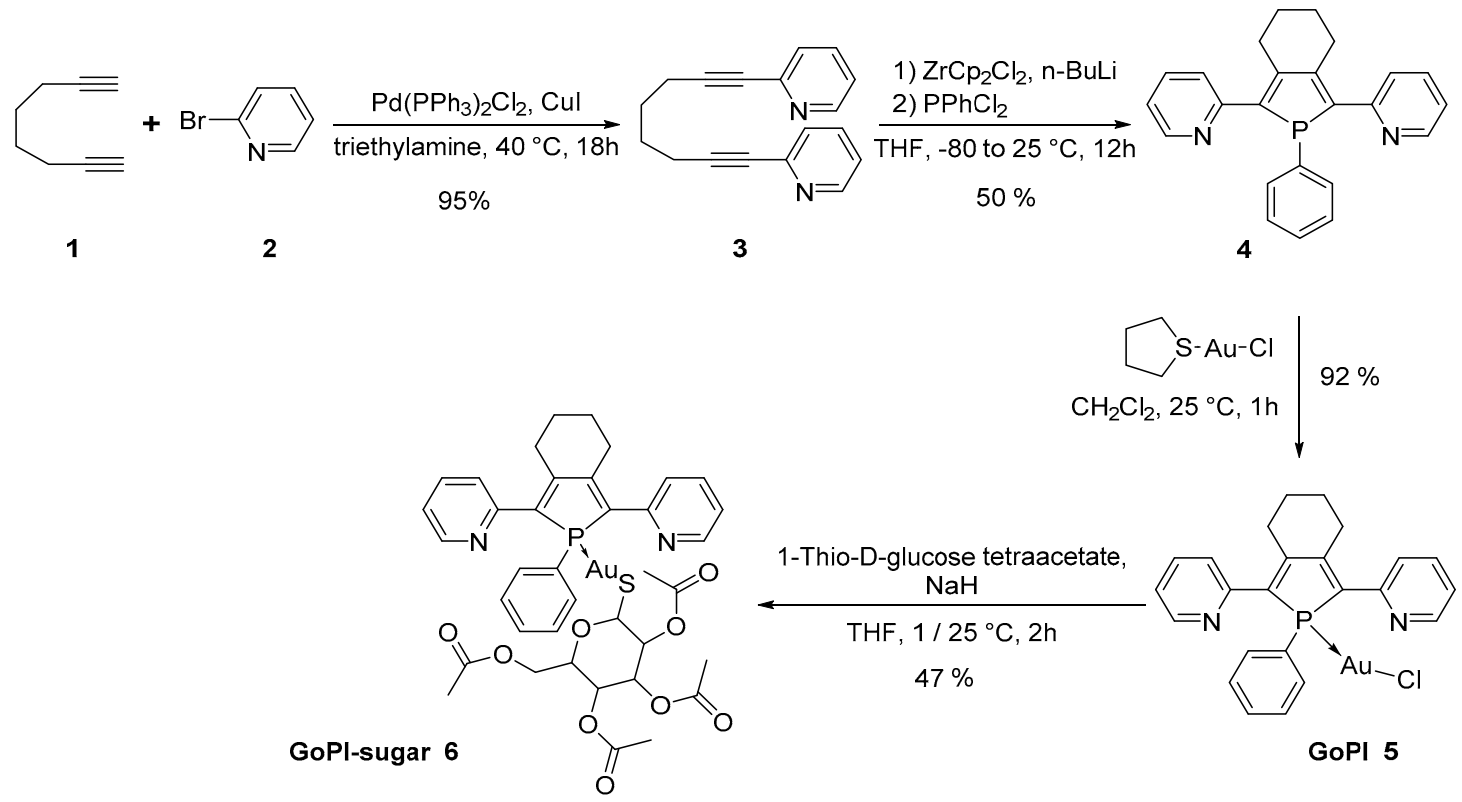

Scheme 1. Synthetic route to prepare 1-thio- $\beta$-D-glucopyranose 2,3,4,6-tetraacetato-S-Au\{1-phenyl2,5-di(2-pyridyl)phosphole\} (GoPI-sugar).

\subsection{Anthelmintic Activity of Gold(I) Complexes}

\subsubsection{Schistosoma mansoni}

Schistosomiasis, also called bilharziasis, is a parasitic disease affecting over 200 million people and causing 280,000 deaths per year in many tropical areas [41]. Praziquantel has been used to cure schistosomiasis since the 1980s, but this drug is not effective against immature worms and is currently the only available medication. The anti-malarial drug artemether has been investigated as a new drug for schistosomiasis; however, in order to protect artemisinin-based drugs from development of drug resistance in the malaria parasite, artemether is not widely used to treat schistosomiasis [42].

Flatworms (platyhelminth parasites) were found to have a condensed redox network, with the activities of TrxR and GR found in a single protein thioredoxin glutathione reductase (TGR) and with authentic GR and TrxR proteins being absent [34,43-45]. TGR has been found to be an essential and druggable protein $[24,46]$. The catalytic mechanism of TGR proteins has been examined by both biochemical and structural approaches $[47,48]$. Gold compounds have been found to inhibit TGR from numerous helminths and to have in vitro worm-killing activity [24,49-51], and the mechanism of inhibition by auranofin has been examined in detail [27]. It was found that auranofin reduced worm burdens in S. mansoni infected mice, likely through inhibition of TGR [24]. This reduction was partial $(\sim 60 \%)$ and resulted only after multiple doses, factors reducing the prospects for repositioning auranofin for schistosomiasis treatment. This inspired us to seek alternative compounds, which might display more potent anti-Schistosoma activity. 
Table 1. Inhibition of human and parasitic NADPH-dependent disulfide reductases: data from the literature and original data (blue background).

\begin{tabular}{|c|c|c|c|c|c|c|c|c|c|c|}
\hline Enzymes & $\begin{array}{c}\text { Human } \\
\text { TrxR }[13,15]\end{array}$ & $\begin{array}{l}\text { Human TrxR } \\
{[11,13-15,52]}\end{array}$ & Human TrxR [11] & $\begin{array}{l}\text { Human GR } \\
{[11-13,15]}\end{array}$ & \multicolumn{3}{|c|}{ S. mansoni TGR [24] } & \multirow{2}{*}{$\begin{array}{c}\begin{array}{c}\text { L. infantum TR } \\
\text { [31] }\end{array} \\
\mathrm{TS}_{2}\end{array}$} & \multirow{2}{*}{$\begin{array}{c}\begin{array}{c}\text { S. mansoni } \\
\text { TGR }\end{array} \\
\text { DTNB }\end{array}$} & \multirow{2}{*}{$\begin{array}{c}\begin{array}{c}\text { B. pahangi } \\
\text { TrxR }\end{array} \\
\text { DTNB }\end{array}$} \\
\hline Substrates & $h \operatorname{Trx}{ }^{C 72 S}$ & DTNB & E. coli $\operatorname{Tr} x S_{2}$ & GSSG & DTNB & GSSG & $\begin{array}{l}\text { HED + } \\
\text { GSSG }\end{array}$ & & & \\
\hline \multicolumn{11}{|c|}{$\begin{array}{c}\text { Gold(I) Complexes IC } \mathbf{I}_{\mathbf{5 0}} \text { (nM) } \\
\text { (enzyme concentration, substrate concentration) }\end{array}$} \\
\hline Auranofin & & $\begin{array}{l}20(2 \mathrm{nM} \\
3 \mathrm{mM})^{2}\end{array}$ & $\begin{array}{c}\mathrm{K}_{i}=2.0 \text { and } 3.0 \\
\mathrm{nM}(1.7 \mathrm{nM}, \text { at } 50 \\
\text { and } 75 \mathrm{Tr} x \mathrm{~S}_{2} \\
\text { respectively })^{2}\end{array}$ & $\begin{array}{c}40,000(1.5 \\
\mathrm{nM}, 1 \mathrm{mM})^{2}\end{array}$ & $\begin{array}{l}7(20 \mathrm{nM} \\
3 \mathrm{mM})^{3}\end{array}$ & $\begin{array}{l}9(20 \mathrm{nM}, \\
100 \mu \mathrm{M})^{3}\end{array}$ & $\begin{array}{l}6(20 \mathrm{nM} \\
8 \mathrm{mM})^{3}\end{array}$ & $\begin{array}{c}\mathrm{K}_{i}=155 \pm 35 \mathrm{nM} \\
(40 \mathrm{nM} \\
50-400 \mu \mathrm{M})^{2}\end{array}$ & $\begin{array}{c}1.1 \\
(20 \mathrm{nM} \\
3 \mathrm{mM})^{3}\end{array}$ & $\begin{array}{c}0.5 \\
(20 \mathrm{nM}, \\
3 \mathrm{mM})^{3}\end{array}$ \\
\hline GoPI & $\begin{array}{c}6.9(24 \mathrm{nM}, \\
20 \mu \mathrm{M})^{1} \\
7(30 \mathrm{nM} \\
20 \mu \mathrm{M})^{1}\end{array}$ & $\begin{array}{c}0.8(4.8 \mathrm{nM}, \\
3 \mathrm{mM})^{1} \\
1(3.7 \mathrm{nM} \\
3 \mathrm{mM})^{1}\end{array}$ & & $\begin{array}{c}1(1.4 \mathrm{nM}, \\
100 \mu \mathrm{M})^{1} \\
2(1.4-2.8 \mathrm{nM}, \\
100 \mu \mathrm{M})^{1}\end{array}$ & & & & & & \\
\hline GoPI-sugar & $\begin{array}{c}4.3 \pm 1.6 \\
(30 \mathrm{nM} \\
20 \mu \mathrm{M})\end{array}$ & $\begin{array}{l}0.49 \pm 0.04 \\
(3.7 \mathrm{nM} \\
3 \mathrm{mM})^{1}\end{array}$ & & $\begin{array}{c}88.5 \pm 28 \\
(1.4-2.8 \mathrm{nM} \\
100 \mu \mathrm{M})^{1}\end{array}$ & & & & & $\begin{array}{c}12.5 \\
(40 \mathrm{nM} \\
3 \mathrm{mM})^{1}\end{array}$ & $\begin{array}{c}5.5 \\
(100 \mathrm{nM} \\
3 \mathrm{mM})^{1}\end{array}$ \\
\hline Aurothioglucose & & $\begin{array}{l}65(2 \mathrm{nM}, \\
3 \mathrm{mM})^{2}\end{array}$ & & $\begin{array}{l}>100,000 \\
(1.5 \mathrm{nM}, \\
1 \mathrm{mM})^{2}\end{array}$ & $\begin{array}{c}70 \\
(20 \mathrm{nM}, \\
3 \mathrm{mM})^{3}\end{array}$ & $\begin{array}{c}3000 \\
(20 \mathrm{nM} \\
100 \mu \mathrm{M})^{3}\end{array}$ & $\begin{array}{c}400 \\
(20 \mathrm{nM} \\
8 \mathrm{mM})^{3}\end{array}$ & & & \\
\hline Aurothiomalate & & $\begin{array}{l}280(2 \mathrm{nM} \\
3 \mathrm{mM})^{2,4}\end{array}$ & & & $\begin{array}{c}90 \\
(20 \mathrm{nM} \\
3 \mathrm{mM})^{3}\end{array}$ & $\begin{array}{c}50 \\
(20 \mathrm{nM}, \\
100 \mu \mathrm{M})^{3}\end{array}$ & $\begin{array}{c}50 \\
(20 \mathrm{nM} \\
8 \mathrm{mM})^{3}\end{array}$ & & & \\
\hline
\end{tabular}

Condition of enzyme inhibition: ${ }^{1}$ after 10 min. of enzyme-NADPH-gold complex preincubation [12]; ${ }^{2}$ in steady state kinetic studies [11]; ${ }^{3}$ after 15 min. of enzyme-NADPH-gold complex preincubation [24]; ${ }^{4}$ mitochondrial TrxR2 was used instead of the cytosolic TrxR1 [52]. Substrate abbreviations stand for: 5,5-dithio-bis-(2-nitrobenzoic acid) (DTNB); glutathione disulfide (GSSG); 2-hydroxyethyl disulfide (HED); oxidized E. coli thioredoxin ( $\operatorname{TrxS}_{2}$ ); oxidized human thioredoxin mutated at C72S (hTrxC72S); trypanothione disulphide (TS ${ }_{2}$ ). 
Both auranofin and GoPI-sugar had similar enzymatic inhibitory activities against TGR enzyme activity with $\mathrm{IC}_{50}$ values in the low $\mathrm{nM}$ range (Table 1). GoPI-sugar killed ex vivo S. mansoni worms with similar activity to auranofin with $2.5 \mu \mathrm{M}$ resulting in $100 \%$ death in 2 days for auranofin and 5 days for GoPI-sugar (Table 2). These effective concentrations might be reached in the plasma after oral administration if we rely on the mean gold maximum concentration in plasma (Cmax) at day 7 of $0.312 \mu \mathrm{g} / \mathrm{mL}$ (ca. $0.46 \mu \mathrm{M}$ ) known for auranofin [53].

Table 2. Comparison of the worm killing activity of auranofin and GoPI-sugar against S. mansoni using a phenotypic assay [54] in adult ex vivo $S$. mansoni worms.

\begin{tabular}{ccccccc}
\hline Compound & Conc. $(\mu \mathrm{M})$ & $\begin{array}{c}\text { Dead (\%) } \\
\text { Day 1 }\end{array}$ & $\begin{array}{c}\text { Dead (\%) } \\
\text { Day 2 }\end{array}$ & $\begin{array}{c}\text { Dead (\%) } \\
\text { Day 3 }\end{array}$ & $\begin{array}{c}\text { Dead (\%) } \\
\text { Day 4 }\end{array}$ & $\begin{array}{c}\text { Dead (\%) } \\
\text { Day 5 }\end{array}$ \\
\hline Auranofin & 10 & 100 & & & & \\
GoPI-sugar & 10 & 100 & & & & \\
\hline Auranofin & 5 & 100 & & & & \\
GoPI-sugar & 5 & 100 & & & & \\
\hline Auranofin & 2.5 & 50 & 100 & 0 & 50 & 100 \\
GoPI-sugar & 2.5 & 0 & 0 & 0 & 0 & 0 \\
\hline Auranofin & 1 & 0 & 0 & 0 & 0 & 0 \\
GoPI-sugar & 1 & 0 & 0 & 0 & & \\
\hline
\end{tabular}

\subsubsection{Filarial Parasites}

Onchocerciasis, or river blindness, caused by Onchocerca spp., lymphatic filariasis or elephantiasis, caused by Brugia pahangi and other species, and Loiasis also known as the eye worm, caused by Loa loa, are neglected tropical diseases that affect millions of people. These result from infection with filarial nematodes. There are no drugs available against adult filarial worms suitable for mass drug administration and existing drugs mainly kill the first-stage larvae (microfilariae). These drugs can reduce the transmission of infection but the adult worms continue to produce microfilariae and perpetuate infection. Finding a drug that could kill the adult worms would be an important tool in eliminating filarial infections. Recently, it was found that auranofin kills adult filarial worms and reduces the worm burden in B. pahangi infected gerbils, likely through inhibition of filarial TrxR activity [36]. Both auranofin and GoPI-sugar have similar enzymatic inhibitory activities against TrxR enzyme activity with $\mathrm{IC}_{50}$ values in the low $\mathrm{nM}$ range (Table 1 ). The in vitro anti-B. pahangi activity against adult worms of auranofin and GoPI-sugar were similar at 3 and $10 \mu \mathrm{M}$, with auranofin being more active at $1 \mu \mathrm{M}$ (Table 3). The compounds had $\mathrm{LD}_{50}$ in the low micromolar range for GoPI-sugar and the submicromolar range for auranofin for activity against female B. pahangi (Table 4).

Table 3. Comparison of the worm killing activity of auranofin and GoPI-sugar with female B. pahangi worms in an in vitro motility assay [55]. Percent inhibitions are the average of $n=4$ worms per concentration compared to vehicle treated worms.

\begin{tabular}{cccccc}
\hline \multirow{2}{*}{ Compound } & Conc. $(\boldsymbol{\mu M})$ & \multicolumn{4}{c}{ Inhibition of Motility } \\
\cline { 3 - 6 } & & $\mathbf{( \% )}$ Day $\mathbf{1}$ & $\mathbf{( \% )}$ Day $\mathbf{2}$ & $\mathbf{( \% )}$ Day 3 & $(\mathbf{\%})$ Day 6 \\
\hline Auranofin & 10 & 99 & 100 & 99 & 98 \\
GoPI-sugar & 10 & 91 & 98 & 100 & 99 \\
\hline Auranofin & 3 & 98 & 100 & 99 & 98 \\
GoPI-sugar & 3 & 24 & 41 & 40 & 96 \\
\hline Auranofin & 1 & 25 & 45 & 48 & 98 \\
GoPI-sugar & 1 & 20 & 16 & 22 & 48 \\
\hline
\end{tabular}


Table 4. $\mathrm{IC}_{50}$ data of auranofin and GoPI-sugar for adult female Brugia pahangi worms using the worminator in vitro motility assay. Each compound was tested using a six-point serial dilution, $\mathrm{n}=$ four worms per concentration; $\mathrm{R}^{2} \geq 0.7$ for all $\mathrm{IC}_{50} \mathrm{~s}$.

\begin{tabular}{cccc}
\hline Compound & IC $_{\mathbf{5 0}}(\boldsymbol{\mu M})$ Day $\mathbf{2}$ & IC $_{\mathbf{5 0}}(\boldsymbol{\mu M})$ Day $\mathbf{3}$ & IC $_{\mathbf{5 0}}(\boldsymbol{\mu M})$ Day $\mathbf{6}$ \\
\hline Auranofin & 0.6 & 0.7 & 0.4 \\
GoPI-sugar & 2.8 & 3.9 & 1.7 \\
\hline
\end{tabular}

GoPI-sugar was tested against O. ochengi, the Onchocerca species infecting cattle, and L. loa microfilariae. $O$. ocheng $i$ is an excellent surrogate for $O$. volvulus since this latter species only infects humans and non-human primates. Loa loa microfilariae are particularly important to use in counter-screens because microfilaricidal drugs (e.g., ivermectin) have been known to cause severe adverse effects in individuals co-infected with a high numbers of $L$. loa [56,57]. Thus, a macrofilaricidal drug that kills only adult filarial worms and not $L$. loa microfilariae would be ideal in co-endemic areas. Such behavior was found in the activity profile of GoPI-sugar (Table 5). GoPI-sugar was equally active as auranofin against adult male and microfilariae of $O$. ochengi. GoPI-sugar was, however, less active than auranofin against female $O$. ochengi and against $L$. loa microfilariae.

Table 5. Comparison of the motility inhibition of auranofin and GoPI-sugar against O. ochengi adults and microfilariae (mf) and L. loa microfilariae.

\begin{tabular}{cccccc}
\hline Compound & Conc. $(\mu \mathrm{M})$ & $\begin{array}{c}\text { O. ochengi } \\
\text { Adult Female } \\
\text { Day 7 }\end{array}$ & $\begin{array}{c}\text { O. ochengi } \\
\text { Adult Male } \\
\text { Day 5 }\end{array}$ & $\begin{array}{c}\text { O. ochengi } \\
\text { mf } \\
\text { Day 5 }\end{array}$ & $\begin{array}{c}\text { L. loa } \text { mf } \\
\text { w/MK2 Cells } \\
\text { Day 5 }\end{array}$ \\
\hline Auranofin & 10 & 100 & 100 & 100 & 63 \\
\hline GoPI-sugar & 10 & 51 & 100 & 100 & 38 \\
\hline
\end{tabular}

\subsection{Anti-Kinetoplastid Activity of Gold(I) Complexes}

\subsubsection{Trypanothione Reductase from Kinetoplastidae}

African sleeping sickness (Trypanosoma brucei gambiense, T. $b$. rhodesiense), South American Chagas' disease (T. cruzi), Nagana cattle disease (T. congolense, T. b. brucei), and the different forms of leishmaniasis due to Leishmania spp. are parasitic diseases due to kinetoplastidae parasites. These protozoan parasites maintain a reducing intracellular milieu and thus protection from oxidative stress thanks to a unique system based on trypanothione reductase (TR). In kinetoplastids, GSH is replaced by trypanothione, a bis(glutathionyl)spermidine conjugate, and GR by TR [58]. The trypanothione system not only replaces the glutathione system but also the thioredoxin system in these organisms. $T R$ is a validated drug target for anti-trypanosomal and anti-leishmanial drugs. Different genetic approaches have unequivocally shown that TR is essential. Bloodstream African trypanosomes with less than $10 \%$ of wild-type activity were unable to grow, although the levels of reduced trypanothione and total thiols remained constant. The parasites were highly sensitive to $\mathrm{H}_{2} \mathrm{O}_{2}$ and were incapable of establishing infection in mice [59]. The de novo synthesis of trypanothione and residual levels of TR are adequate to maintain resting thiol levels, but insufficient to cope with oxidative stress situations.

A number of TR inhibitors have been developed and some of them are fairly effective, in particular the compounds that possess two reactive sites-bis(Michael acceptors and thiophilic metal complexes-towards enzyme dithiols or trypanothione itself (for a review, ref. [60]). These inhibitors include unsaturated Mannich bases [61], curcuminoid derivatives [62,63], arsenicals [64] and antimonials [65]; the latter two have been used for the treatment of sleeping sickness and leishmaniasis, respectively, for more than a decade. More recently, auranofin was found to be a very effective L. infantum TR inhibitor and a moderate anti-leishmanial agent. The X-ray crystal structure of the 
auranofin-TR-NADPH complex was solved at $3.5 \AA$ A resolution, showing gold bound to the two active site cysteine residues of TR, i.e., Cys52 and Cys57, while the thiosugar moiety was bound to the trypanothione binding site [31]. This finding has stimulated our interest to test GoPI-sugar against kinetoplastid parasites.

\subsubsection{Trypanosoma b. gambiense and T. b. brucei}

Gold(I) complexes were found to be potent inhibitors of TR with very low $\mathrm{IC}_{50}$ values [31]. However, no study on their anti-trypanosomal action has yet been reported. Based on previous oral pharmacokinetic studies of auranofin [7], 15-25\% of the drug remains in the plasma $1-2 \mathrm{~h}$ after administration and the plasma concentration was found to be $10 \mu \mathrm{g} / \mathrm{mL}$, well above the concentrations resulting in in vitro parasite death.

Here, we compared the anti-T. b. gambiense and anti-T. b. brucei activity of auranofin and GoPIsugar (Table 6): both gold(I) complexes exhibited high anti-trypanosomal activities with $\mathrm{IC}_{50}$ at $1.11 \pm$ $0.12 \mu \mathrm{M}$ for GoPI- sugar and $0.21 \pm 0.01 \mu \mathrm{M}$ for auranofin. Similar activities were obtained against T. $b$. brucei (Table 6).

Table 6. In vitro activities of gold(I) complexes in T. b. gambiense and T. b. brucei trypomastigotes.

\begin{tabular}{ccc}
\hline Compounds & $\begin{array}{c}\text { T. } \boldsymbol{b} . \text { gambiense } \\
\mathbf{I C}_{\mathbf{5 0}}(\boldsymbol{\mu M}) \pm \mathrm{SD}\end{array}$ & $\begin{array}{c}\text { T. } \boldsymbol{b} \text {. } \text { brucei } \\
\mathbf{I C}_{\mathbf{5 0}}(\boldsymbol{\mu M})\end{array}$ \\
\hline Auranofin & $0.21 \pm 0.01$ & 0.50 \\
\hline GoPI-sugar & $1.11 \pm 0.12$ & 1.83 \\
\hline Miltefosine $^{1}$ & $\mathrm{ND}$ & 11.35 \\
\hline Pentamidine $^{1}$ & $0.0011 \pm 0.0001$ & $\mathrm{ND}$ \\
\hline Suramin $^{1}$ & $\mathrm{ND}$ & 0.03 \\
\hline${ }^{2}$ &
\end{tabular}

\subsubsection{Trypanosoma cruzi and Leishmania infantum}

Auranofin has been shown to possess in vitro and in vivo activity against T. cruzi [30], as well as stimulating apoptosis in L. major and L. amazonensis with promising in vitro and in vivo anti-leishmanial activities [66]. Moreover, studies showed that this drug is an effective inhibitor of TR in L. infantum [31]. GoPI-sugar displayed low $\mathrm{IC}_{50}$ values against both T. cruzi and L. infantum (Table 7).

Against $L$. infantum amastigotes, auranofin displayed equal $\mathrm{IC}_{50}$ and $\mathrm{CC}_{50}$ values in the assays with mouse macrophages, illustrative for a non-specific activity.

Table 7. In vitro activities of gold(I) complexes in T. cruzi and L. infantum amastigotes.

\begin{tabular}{ccc}
\hline Compounds & $\begin{array}{c}\text { Trypanosoma cruzi } \\
\mathbf{I C}_{\mathbf{5 0}}(\boldsymbol{\mu M}) \pm \mathrm{SD}\end{array}$ & $\begin{array}{c}\text { Leishmania infantum } \\
\mathbf{I C}_{\mathbf{5 0}}(\boldsymbol{\mu M}) \pm \mathrm{SD}\end{array}$ \\
\hline Auranofin & $<0.25$ & $2.03 \pm 0.76$ \\
\hline GoPI-sugar & $0.56 \pm 0.11$ & 2.38 \\
\hline Miltefosine $^{1}$ & $\mathrm{ND}$ & $11.35 \pm 2.88$ \\
\hline Benznidazole $^{1}$ & $2.89 \pm 0.94$ & $\mathrm{ND}$
\end{tabular}

${ }^{1}$ Miltefosine and Benznidazole were used as drug controls.

\subsubsection{Leishmania donovani}

Trypanothione synthetase and TR are essential proteins for Leishmania parasite survival. As auranofin was shown to be a potent TR inhibitor with anti-Leishmania activity, we tested both compounds against axenic and intramacrophage amastigotes of L. donovani LV9. The $\mathrm{IC}_{50}$ values determined confirmed the potent anti-Leishmania activity of auranofin within the expected plasma 
concentration of auranofin after oral administration (Table 8). Substantially higher anti-Leishmania activities were reported against L. major and L. amazonensis with $\mathrm{IC}_{50} \mathrm{~s}$ of $0.07 \mu \mathrm{M}$ and $0.27 \mu \mathrm{M}$, respectively [66]. We found that GoPI-sugar was very effective at inhibiting the growth of intramacrophage amastigotes with an $\mathrm{IC}_{50}$ of $0.42 \pm 0.15 \mu \mathrm{M}$ versus $0.70 \pm 0.24 \mu \mathrm{M}$ for auranofin (Table 8). Regarding the cytoxicity of GoPI-sugar at $4 \mu \mathrm{M}$ on murine RAW 264.7 macrophages, its selectivity index of $\sim 10$ is moderate, but improvable (Table 9).

Table 8. In vitro activities of gold(I) complexes in L. donovani LV9 axenic amastigotes and intramacrophage amastigotes.

\begin{tabular}{ccc}
\hline Compounds & $\begin{array}{c}\text { Leishmania donovani LV9 } \\
\text { Axenic Amastigotes } \\
\mathbf{I C}_{\mathbf{5 0}}(\boldsymbol{\mu M}) \pm \mathbf{S D}\end{array}$ & $\begin{array}{c}\text { Leishmania Donovani LV9 } \\
\text { Intramacrophage Amastigotes } \\
\mathbf{I C}_{\mathbf{5 0}}(\boldsymbol{\mu m}) \pm \text { SD }\end{array}$ \\
\hline Auranofin & $0.56 \pm 0.03$ & $0.70 \pm 0.24$ \\
\hline GoPI-sugar & $1.45 \pm 0.07$ & $0.42 \pm 0.15$ \\
\hline Miltefosine $^{1}$ & $1.28 \pm 0.12$ & $4.49 \pm 1.08$ \\
\hline \multicolumn{3}{c}{}
\end{tabular}

Table 9. In vitro activities of gold(I) complexes against A. castellanii and RAW 264.7 macrophages.

\begin{tabular}{ccc}
\hline Compounds & $\begin{array}{c}\text { Acanthamoeba castellanii ATCC 30010 } \\
\text { IC }_{\mathbf{5 0}}(\boldsymbol{\mu M}) \pm \text { SD }\end{array}$ & $\begin{array}{c}\text { Cytotoxicity on RAW 264.7 Macrophages } \\
\text { CC }_{\mathbf{5 0}}(\boldsymbol{\mu M}) \pm \text { SD }\end{array}$ \\
\hline Auranofin & $5.79 \pm 1.02$ & $4.43 \pm 0.08$ \\
\hline GoPI-sugar & $13.04 \pm 1.53$ & $4.35 \pm 0.04$ \\
\hline Miltefosine & $9.21 \pm 2.04$ & $>25$ \\
\hline Pentamidine & $1.39 \pm 0.37$ & $>25$ \\
\hline
\end{tabular}

\subsection{Anti-Amoeba Activity of Gold(I) Complexes}

\section{Acanthamoeba castellanii}

Entamoeba histolytica, the causative agent of human amebiasis, lacks both GR activity and glutathione synthetic enzymes. Its TrxR is involved in prevention, intervention and repair of damage caused by oxidative stress. The discovery of the amebicidal activity of auranofin has repositioned this drug for the treatment of amebiasis [35]. Transcriptional profiling and direct assays indicated that auranofin likely targets the E. histolytica TrxR in vivo [53]. Acanthamoeba spp. are free living amoeba, which possess mitochondria and live in an aerobic environment. As such, Acanthamoeba spp. can synthesize glutathione and have authentic GR in addition to $\operatorname{TrxR}[67,68]$. A. castellanii acts as an opportunistic parasite and may cause ulcerative keratitis or granulomatous encephalitis.

Our evaluation of the activity against $A$. castellanii [69] showed that auranofin and GoPI-sugar displayed anti-acanthamoebal activity with $\mathrm{IC}_{50}$ at $13.04 \pm 1.53 \mu \mathrm{M}$ and $5.79 \pm 1.02 \mu \mathrm{M}$, respectively (Table 9). However, both displayed a cytotoxicity at around $4 \mu \mathrm{M}$ on macrophages leading to a low selectivity index.

\subsection{Activity of GoPI-Sugar against Theileria-Transformed Leukocytes}

Tropical theileriosis caused by T. annulata severely affects cattle production in the Middle East and Asia. This apicomplexan parasite causes a lymphoproliferative disease, with similarities to human lymphomas and myeloid leukemias. Theileria annulata infects bovine B cells and macrophages/ monocytes $[70,71]$ resulting in a perpetual host cell proliferation. Live vaccines exist only for tropical theileriosis [72] and are generated in vitro by attenuation of live parasites by several passages of infected monocytes/macrophages. These attenuated cells are characterized by the loss of their hyper-disseminating virulence trait $[73,74]$. Known as the only eukaryote pathogen to transform a 
eukaryote host cell, Theileria is able to manipulate host cell signaling pathways (for a review, ref. [75]) such as TGF $\beta$ [76-78] and c-Jun N-terminal (JNK) kinase leading to activation of host transcription factors such c-Myc [79,80], NF-kB [81] and AP-1 [73,82-84]. One other characteristic is the induction of oxidative stress, resulting in an increase of ROS including $\mathrm{H}_{2} \mathrm{O}_{2}$ [85].

Buparvaquone is currently the most effective treatment. It is a hydroxylnaphthoquinone that acts by inhibiting the parasite's electron transport chain [75]. It is important to find new medicines not only to fight against possible resistance but also to achieve more efficacious treatment. As the GoPI-sugar has a role in oxidative stress $[15,84]$ and antiproliferative properties on cancer cells [15], we sought to determine the effect of the GoPI-sugar on T. annulate-infected cells. B cells derived from a bovine lymphosarcoma (BL3) were treated at different concentrations of GoPI-sugar ranging from $0.25 \mu \mathrm{M}$ to $3 \mu \mathrm{M}$ to determine a non-toxic concentration (Figure 2).

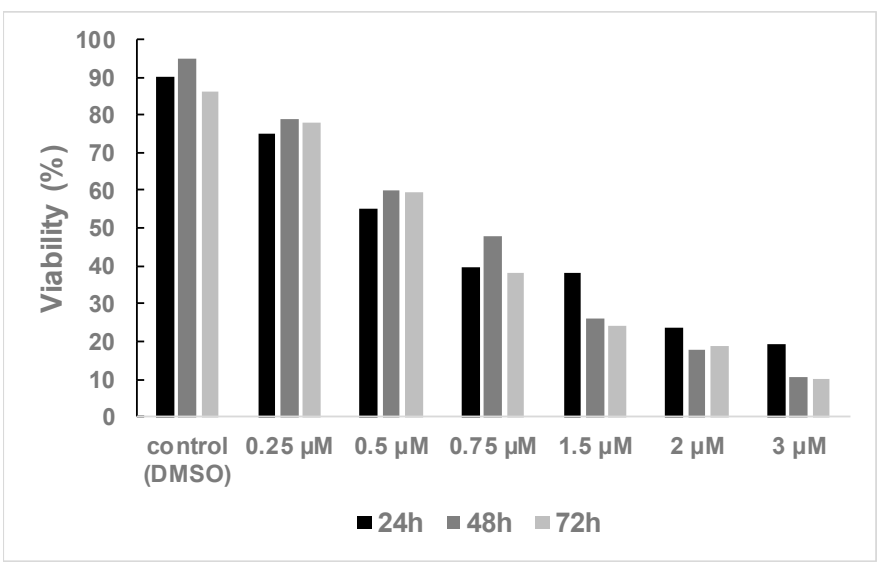

Figure 2. Viability of non-infected bovine lymphosarcoma cells (BL3) after treatment with different concentrations of GoPI-sugar complex.

As $\mathrm{CC}_{50}$ for Go-PI-sugar is approximately $0.5 \mu \mathrm{M}$ (Figure 2), we decided to treat the cells at $0.25 \mu \mathrm{M}$ and $0.5 \mu \mathrm{M}$ to evaluate the antiproliferation effect. We noted that the proliferation of BL3 treated with GoPI-sugar was dampened compared to untreated BL3 cells. This delay is observed as early as $24 \mathrm{~h}$ and is even more marked at $0.5 \mu \mathrm{M}$. For TBL3 cells (BL3 infected with an Indian strain of T. annulata) treated with $0.5 \mu \mathrm{M}$, we first noted a dampened proliferation in the first $24 \mathrm{~h}$ (Figure 3B). In fact, the cells remained at 200,000 cells per well compared to the number of untreated TBL3 cells, which almost doubled in $24 \mathrm{~h}$. At $0.5 \mu \mathrm{M}$, the antiproliferative effect occurred much earlier $(24 \mathrm{~h})$ while this effect was observed later $(72 \mathrm{~h})$ at $0.25 \mu \mathrm{M}$. After $72 \mathrm{~h}$, the number of cells decreased, due to cell death.

A

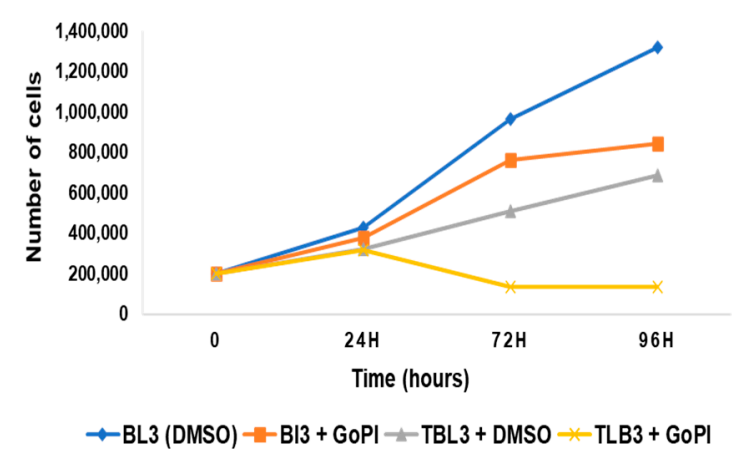

B

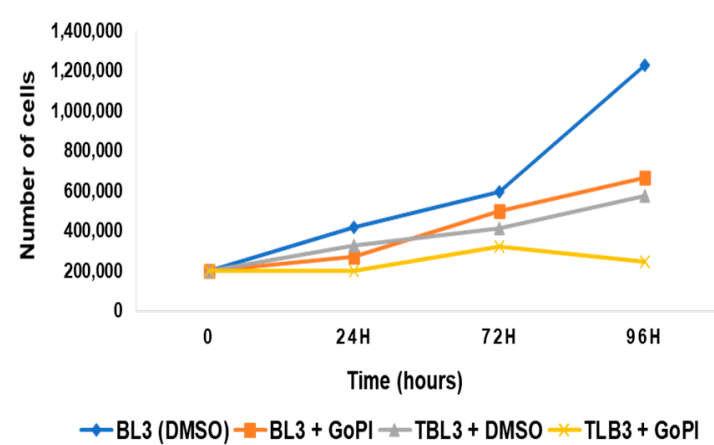

Figure 3. Effects of GoPI-sugar complex on the proliferation of non-infected bovine lymphosarcoma cells (BL3) and Theileria annulata-infected cells (TBL3) treated with GoPI-sugar complex at $0.25 \mu \mathrm{M}$ (A) and $0.5 \mu \mathrm{M}$ (B) for $96 \mathrm{~h}$. 
These results show that GoPI-sugar had an antiproliferative effect on another type of cancer, the BL3 lymphosarcoma. This result is in agreement with previously published data on breast cancers [14] and glioblastoma cells [15]. However, a delay of the proliferation of Theileria-infected cells (TBL3) at $24 \mathrm{~h}$ and after $72 \mathrm{~h}$ of GoPI-sugar treatment was observed, suggesting that the cells started to die. Interestingly, the cytotoxic effect of GoPI-sugar observed in TBL3 cells was absent in BL3 cells after $72 \mathrm{~h}$, the time at which only a slowdown of growth was seen. This suggests that the drug had some specific theilericidal effect. This result appeared to be similar to that observed with buparvaquone after $24 \mathrm{~h}$ of treatment; B cells stop proliferating with arrest in the G0-G1 phase of the cell cycle. Their transformed phenotype is reversed and the cells become dependent on exogenous factors to proliferate. This effect shows that the presence of the parasite is essential for the transformed phenotype. From $48 \mathrm{~h}$ of treatment the cells died by apoptosis or returned to a state of quiescence. The effect of the GoPI-sugar complex thus seems to resemble that of buparvaquone and may warrant more detailed future studies.

\subsection{Cytotoxicity Activity of Gold(I) Complexes}

Toxicity in human fetal lung fibroblast (MRC-5) cell line and primary mouse macrophages (PMM) was assessed using a previously reported assay in 96-well microtiter plates [10]. Tamoxifen and miltefosine were included as reference drugs (Table 10).

Table 10. In vitro cytotoxicity $\left(\mathrm{CC}_{50} \mu \mathrm{M}\right)$ of gold(I) complexes in human fetal lung fibroblast (MRC-5) and primary mouse macrophages (from the L. infantum assay).

\begin{tabular}{ccc}
\hline Compounds & $\begin{array}{c}\text { Cytotoxicity on hMRC-5, } \\
\mathbf{C C}_{\mathbf{5 0}}(\boldsymbol{\mu M})\end{array}$ & $\begin{array}{c}\text { Cytotoxicity on PMM } \\
\mathbf{C C}_{\mathbf{5 0}}(\boldsymbol{M} \mathbf{M})\end{array}$ \\
\hline Auranofin & 0.52 & 2.00 \\
\hline GoPI-sugar & 0.59 & 8.00 \\
\hline Tamoxifen & 10.63 & $\mathrm{ND}$ \\
\hline Miltefosine & $\mathrm{ND}$ & 20.00 \\
\hline
\end{tabular}

${ }^{1}$ PMM: primary mouse macrophages (from the L. infantum assay).

\section{Discussion}

Drug repositioning holds promise for the identification of affordable new treatments for neglected tropical diseases, for which too few effective and nontoxic drugs are available. Repositioned entities account for about $30 \%$ of the drugs and vaccines approved by the US Food and Drug Administration in recent years. Among these, auranofin was selected from high-throughput screens to identify new agents against E. histolytica and entered phase I clinical trials for amebiasis [53]. This demonstrated acceptable safety of auranofin and provided relevant pharmacokinetic data to support the idea of its use as a broad-spectrum antiparasitic drug.

Here we find that auranofin has low or sub-micromolar killing in vitro activity against all parasites tested, from worm to single cell protozoa. Previous studies have found that auranofin has significant activity against several of these parasites in animal models of infection. Given the promising results in human clinical studies with auranofin for treating amebiasis, the results presented here indicate that auranofin may have much broader clinical potential use.

A second aim of this study was to determine the activity of a new gold (I) compound, GoPI-sugar, against a wide variety of parasites. We particularly focused on the development of GoPI-sugar, starting from a hit-to-lead molecule, still requiring improvement in both pharmacokinetic and toxicological properties. In comparison with auranofin, we find that GoPI-sugar has similar activities, with killing at low micromolar or high nanomolar concentrations against all species tested. GoPI-sugar exerted its most promising antiparasitic activities against $L$. donovani intramacrophage amastigotes and the helminths S. mansoni and B. pahangi, responsible for two major neglected tropical diseases. 
It is relevant to note that both auranofin and GoPI-sugar showed non-negligible cytotoxic effects against mammalian cells, indicating that further compound engineering, either directly or via formulations based on nanotechnologies, is required. However, auranofin has been approved for clinical use and has been used for RA treatment for many years, with acceptable toxicology and efficacy. Treating infectious diseases will require different therapy regimens than RA. While RA requires long-term treatment with auranofin to alleviate RA symptoms, but not curing the disease, treatment of infectious disease will require one or a few administrations for elimination of the infectious agent and effect a cure. Differences in the basic redox biochemistry found in different eukaryotic organisms, with dependence on unusual redox cofactors and enzymes, like trypanothione and TR, and unique dependences on different enzymes, such as TGR, can be exploited to selectively target pathogens over host. With this is taken into consideration, auranofin and other gold(I) containing compounds show great potential for use in a wide range of parasitic diseases, which is supported by results generated in the present study.

On the other hand, liposomal amphotericin B (AmBisome ${ }^{\circledR}$ ) illustrates the proof-of-concept of anti-leishmanial application of first-generation nanotechnology that resulted in improved drug efficacy and reduced toxicity allowing safer and shorter treatments [86]. Work from Sundar S. et al. demonstrated the comparable efficacy of a single-application regimen of AmBisome ${ }^{\circledR}$ in comparison with the multiple dose conventional treatment with amphotericin B deoxycholate in an open-label clinical trial for visceral leishmaniasis [87]. In the field of anticancer drugs, chemo/photothermal combination therapy based on dual drug co-delivery nanoplatform systems linking two anticancer agents, not only raising the drug loading content, cellular uptake and $\mathrm{pH}$-responsive release rate, but also exhibiting high photothermal activity against tumor cells, considerably improved the therapeutic index of the final nanoformulations [88]. Future work will aim at building nanoparticles of gold(I) complexes with enhanced penetration for efficient antiparasitic chemotherapy allowing improved delivery of the active gold(I) principles.

\section{Materials and Methods}

\subsection{Reagents and Tested Gold(I) Complexes}

Auranofin was purchased from ICN. A new batch of GoPI-sugar was synthesized according to reported procedures [15]. For in vitro assays, compound stock solutions were prepared in 100\% DMSO at $20 \mathrm{mM}$. Compounds were 2-fold serially diluted in DMSO followed by a further (intermediate) dilution in demineralized water to ensure a final in-test DMSO concentration of $<1 \%$.

\subsection{Helminth TGR Enzyme Assays}

Enzymes were prepared in E. coli as described [24,36]. Assays were performed at $25^{\circ} \mathrm{C}$ in $0.1 \mathrm{M}$ potassium phosphate (pH 7.4), 10 mM EDTA using $100 \mu \mathrm{M}$ NADPH and $3 \mathrm{mM}$ dithiobis(2-nitrobenzoic acid) (DTNB) [24]. $\mathrm{IC}_{50}$ values were determined using the indicated concentration of enzyme with a 10 min preincubation with enzyme, compounds, and NADPH followed by addition of substrate DTNB and $100 \mu \mathrm{M}$ NADPH. The increase in $\mathrm{A}_{412}$ during the first 3 min was recorded upon DTNB addition. The reaction was done in triplicate.

\subsection{In Vitro Activity on Schistosoma and Filarial Worms}

Adult ex vivo Schistosoma assay: Mice (Swiss-Webster) were infected with S. mansoni by percutaneous exposure for $1 \mathrm{~h}$ to cercariae (NMRI strain) obtained from infected Biomphalaria glabrata snails. This study was approved by the Institutional Animal Care and Use Committee of Rush University Medical Center (17-053; Department of Health and Human Services animal welfare assurance number A-3120-01). Adult worms were isolated from infected mice as described [89] and cultured in RPMI medium $+10 \%$ fetal calf serum (FCS), $10 \mathrm{mM}$ glutamine, $100 \mathrm{IU} / \mathrm{mL}$ penicillin and $100 \mu \mathrm{g} / \mathrm{mL}$ streptomycin for $24 \mathrm{~h}$ before compound addition. Compounds were dissolved in DMSO 
and added at the indicated concentrations. The culture media was replaced every day and fresh compounds added. Control worms were treated with DMSO alone. Worms were cultured for 5 days. Motility and viability was scored daily using published methods [54] in which a viability score of $3=$ motile, no changes to morphology, transparency and intact tegument, active ventral and oral sucker, paired, attached to surface; 2 = reduced motility and/or some damage to tegument, reduced transparency and granularity, some unpairing and loss of surface adherence; 1 = severe reduction of motility and/or damage to tegument observed, with high opacity and high granularity, few or no paired worms, more loss of surface adherence; $0=$ dead, the worms appear darkened and motility of the ventral and oral sucker is absent, and they displayed no movement over several min. Assays were done in triplicate with about 10 worms in each well. This study was approved by the Institutional Animal Care and Use Committee of Rush University Medical Center (17-053; Department of Health and Human Services animal welfare assurance number A-3120-01).

Adult in vitro Brugia pahangi assay: Adult female B. pahangi worms were kindly provided by Dr. Brenda Beerntsen, University of Missouri, Columbia, MO. Individual female worms were assayed in $500 \mu \mathrm{L}$ of culture medium (RPMI-1640 with $25 \mathrm{mM} \mathrm{HEPES,} 2.0 \mathrm{~g} / \mathrm{L} \mathrm{NaHCO} 3,5 \%$ heat-inactivated FBS and antibiotic/antimycotic solution) in 24-well plates [36]. Worms treated with 1\% DMSO served as negative control and there were four replicates per compound. Worms were maintained at $37^{\circ} \mathrm{C}$ in a $5 \% \mathrm{CO}_{2}$ incubator for the duration of the assay. Individual worm movement was assessed from day 1-6 using the Worminator [55], which reports worm motility as mean movement units (MMU), a measure of pixels displaced. MMUs are then used to calculate percent inhibition of worm motility compared to control worms. IC $_{50}$ were determined using 6-pt serial dilutions $(10,3,1,0.3,0.1,0.03 \mu \mathrm{M})$ and calculated the nonlinear regression curve fit using Prism 7 (Graphpad, La Jolla, CA, USA). All IC 50 results had $R^{2}$ values $\geq 0.7$.

Onchocerca ochengi adult worm assays: For O. ochengi worm assays, subcutaneous nodules containing adult $O$. ocheng $i$ worms were removed from the hides of infected cows collected at abattoirs in Douala, Cameroon. Masses were incubated in $4 \mathrm{~mL}$ of complete culture medium (RPMI-1640, 5\% newborn calf serum, 200 units/mL penicillin, $200 \mu \mathrm{g} / \mathrm{mL}$ streptomycin and $2.5 \mu \mathrm{g} / \mathrm{mL}$ amphotericin B) in standard 12 -well culture plates and maintained in a $37^{\circ} \mathrm{C}, 5 \% \mathrm{CO}_{2}$ incubator overnight during which time the adult males migrated out of the masses while the females remained in the nodules. Compound and control wells (worms in 1\% DMSO) were tested in quadruplicate and experiments were repeated twice on different days. Cultures were terminated on day 7 . Adult male worm viability was visually scored on day 5 as percent reduction of motility ranging from $100 \%$ (complete inhibition of motility), $75 \%$ (worm very sluggish), 50\% (worm sluggish), 25\% (little change in motility) to $0 \%$ (no observable reduction in motility). Adult female worm viability was assessed on day 7 by the standard MTT/formazan assay in which each nodular mass was placed in a well of a 48-well plate containing $500 \mu \mathrm{L}$ of $0.5 \mathrm{mg} / \mathrm{mL}$ MTT (Sigma-Aldrich) in culture medium. Viability was evaluated visually by the extent to which the female worm mass was stained with MTT. Mean percent inhibition of formazan formation was calculated relative to the negative control worm masses after 7 days in culture.

O. ochengi microfilariae assays: were collected from the hides of infected cattle and washed prior to adding 10-15 microfilariae to 96-well culture plates containing confluent monkey kidney epithelial cells in $100 \mu \mathrm{L}$ of media. Microfilariae were run in duplicate and plates were maintained at $37^{\circ} \mathrm{C}$ in a $5 \% \mathrm{CO}_{2}$ incubator. Microfilariae viability was visually scored using percent reduction of motility using the same scoring criteria used for adult males. Scores were recorded every $24 \mathrm{~h}$ after addition of drugs for 5 days using an inverted microscope.

L. loa microfilariae assays: L. loa microfilariae were purified from the blood of infected individuals using a step-wise Percoll gradient (46\% and 43\% Percoll) followed by centrifugation at $400 \mathrm{rcf}$ for $20 \mathrm{~min}$. The microfilariae were recovered in the $43 \%$ layer then assayed using the same culture conditions and method as the O. ochengi microfilariae. 


\subsection{In Vitro Drug Activity against T. b. brucei, T. cruzi and L. infantum}

Anti-leishmanial activity: L. infantum MHOM/MA (BE)/67 amastigotes were collected from the spleen of an infected donor hamster and used to infect primary peritoneal mouse macrophages grown in a 96-well plate. After 2 days outgrowth, $5 \times 10^{5}$ amastigotes were added to each well and incubated for $2 \mathrm{~h}$ at $37^{\circ} \mathrm{C}$. The compounds were subsequently added and the plates were further incubated for 5 days at $37{ }^{\circ} \mathrm{C}$ and $5 \% \mathrm{CO}_{2}$. Parasite burdens (mean number of amastigotes/macrophage) were microscopically assessed on 500 cells after Giemsa staining and expressed as a percentage of the blank controls. Miltefosine was included as reference drug. The use of laboratory rodents was carried out in accordance to all mandatory guidelines (EU directives, including the Revised Directive 2010/63/EU on the Protection of Animals used for Scientific Purposes that came into force on 1 January 2013, and the declaration of Helsinki in its latest version) and was approved by the Ethical Committee of the University of Antwerp, Belgium [UA-ECD 2011-77 (17-02-2012 and UA-ECD 2015-90].

Anti-trypanosomal activity: T. $b$. brucei Squib-427 strain (suramin-sensitive) and T. $b$. gambiense (ITMAP/1893) were cultured at $37^{\circ} \mathrm{C}$ and $5 \% \mathrm{CO}_{2}$ in HMI-9 medium supplemented with $10 \%$ FCS [90]. About $10^{4}$ trypomastigotes/well were added to each well and parasite growth was assessed after $72 \mathrm{~h}$ at $37^{\circ} \mathrm{C}$ by adding resazurin and reading at ex $550 \mathrm{~nm}$, em $590 \mathrm{~nm}$ [91]. Suramin was included as reference drug for T. $b$. brucei and pentamidine for T. $b$. gambiense.

Anti-Chagas activity: T. cruzi Tulahuen CL2 (benznidazole-sensitive, LacZ-reporter strain) [92] was maintained on MRC-5 cells in minimal essential medium (MEM) supplemented with $20 \mathrm{mM}$ L-glutamine, $16.5 \mathrm{mM}$ sodium hydrogen carbonate and $5 \%$ FCS. In the assay, $4 \times 10^{3}$ MRC- 5 cells and $4 \times 10^{4}$ parasites were added to each well. After incubation at $37^{\circ} \mathrm{C}$ for 7 days, parasite growth was assessed by adding the substrate chlorophenol red -D-galactopyranoside. The color reaction was read at $540 \mathrm{~nm}$ after $4 \mathrm{~h}$ and absorbance values were expressed as a percentage of the blank controls. Benznidazole was included as reference drug.

\subsection{In Vitro Drug Activity against L. donovani and A. castellanii}

In vitro anti-leishmanial evaluation was perfomed on both axenic and intramacrophage $L$. donovani amastigotes as previously described [63]. Auranofin and GoPI-sugar were also evaluated in vitro on A. castellanii (ATCC@ $30010^{\mathrm{TM}}$, genotype T4) cultured at $27^{\circ} \mathrm{C}$ in Peptone Yeast-extract Glucose medium (PYG medium; ATCC@ Medium 712) supplemented with 100 units/mL penicillin-streptomycin (Gibco, Life Technologies, Courtaboeuf, France), according to a reported procedure [69]. Briefly, compounds were distributed in 96-well plates using 2-fold dilutions in $100 \mu \mathrm{L} \mathrm{PYG} \mathrm{medium.} \mathrm{A.} \mathrm{castellanii}$ trophozoites were added to each well at $5 \times 10^{4}$ amoeba/mL in $200 \mu \mathrm{L}$ final volume. L. donovani axenic amastigotes were added to each well at $10^{6}$ parasites $/ \mathrm{mL}$ in $200 \mu \mathrm{L}$ final volume. After $72 \mathrm{~h}$ incubation at $27^{\circ} \mathrm{C}, 20 \mu \mathrm{L}$ of $1 \mathrm{mM}$ resazurin was added to each well and further incubated at $27^{\circ} \mathrm{C}$ for $8 \mathrm{~h}$ for A. castellanii and for $24 \mathrm{~h}$ for L. donovani axenic amastigotes. In living cells, resazurin is reduced in resorufin. This conversion is monitored by measuring the absorbance at specific wavelengths of resorufin $(570 \mathrm{~nm})$ and resazurin $(600 \mathrm{~nm})$ using a microplate reader (Labsystems Multiskan MS, McLean, VA, USA). In this assay, the activity was expressed in $\mathrm{IC}_{50}$. Miltefosine and pentamidine were used as reference drugs. All experiments were performed in three independent experiments.

\subsection{In Vitro Drug Activity against Theileria-Transformed Leukocyte}

Theileria annulata culture: The TBL3 cell line was derived by in vitro infection of the spontaneous bovine B-lymphosarcoma cell line BL3 with the Hissar stock of T. annulata. B cell characteristics of the lines have been described [93]. The cells are maintained at $37^{\circ} \mathrm{C}$ under $5 \% \mathrm{CO}_{2}$, in RPMI medium supplemented with 10\% FCS, $25 \mathrm{mM}$ Hepes, $4 \mathrm{mM}$ L-glutamine, $100 \mu \mathrm{g} / \mathrm{mL}$ of streptomycin, $100 \mathrm{IU} / \mathrm{mL}$ of penicillin and $5 \%$ 2-mercapthoethanol.

Cells were cultured in 12-well plates at an initial density of 200,000 cells per well in duplicate for each condition. In the toxicity test, the cells were treated GoPI-sugar ranging from $0.25 \mu \mathrm{M}$ to 
$3 \mu \mathrm{M}$ and cell counting was performed at 24,48 and $72 \mathrm{~h}$ using an automatic cell counter (BIO-RAD TC20TM) and trypan blue to determine cell viability. In the proliferation test, the BL3 and TBL3 cells were treated with GoPI-sugar at the concentration representing the $\mathrm{IC}_{50}$ determined during the toxicity test. The cells were cultured in 12-well plates at an initial density of 200,000 cells per well and drug was added every $24 \mathrm{~h}$. To be able to compare the results, a drug-free control was also performed. Cell counting was done at 24,72 and $96 \mathrm{~h}$ using the trypan blue method.

\subsection{Cytotoxicity on Mammalian Cells}

Cytotoxicity was evaluated on RAW 264.7 macrophages that were maintained at $37^{\circ} \mathrm{C}$ with $5 \%$ $\mathrm{CO}_{2}$ in Dulbecco's Modified Eagle's Medium (DMEM, Invitrogen, Toulouse, France) supplemented with $100 \mathrm{U} / \mathrm{mL}$ penicillin-streptomycin (Invitrogen) and 10\% heat-inactivated fetal bovine serum, as previously described [94]. Briefly, cells were plated in 96-well microplates at a density of $2 \times 10^{4}$ cells per well. After incubation for $24 \mathrm{~h}$ at $37^{\circ} \mathrm{C}$ in $5 \% \mathrm{CO}_{2}$, the medium was removed from each well and $100 \mu \mathrm{L}$ of medium containing 2-fold serial dilutions of compounds was added to each well. After $48 \mathrm{~h}$ incubation at $37^{\circ} \mathrm{C}$ in $5 \% \mathrm{CO}_{2}, 10 \mu \mathrm{L}$ of $450 \mu \mathrm{M}$ resazurin was added to each well and further incubated in the dark for $4 \mathrm{~h}$. Cell viability was determined as described above. The cytotoxicity of the compounds was expressed as $\mathrm{CC}_{50}$.

For MRC5 $5_{\mathrm{SV} 2}$ or PMM cells, the assays were performed in 96-well microtiter plates, each well containing $10 \mu \mathrm{L}$ of compound dilution and $190 \mu \mathrm{L}$ of cell inoculum $\left(3 \times 10^{4}\right.$ cells $\left./ \mathrm{mL}\right)$ as reported [10]. Cell growth was compared to untreated controls (100\% growth) and assay-media controls ( $0 \%$ growth). After three-day incubation, cell viability was assessed fluorometrically by adding resazurin [ $50 \mu \mathrm{L} /$ well of a stock solution in phosphate buffer $(50 \mu \mathrm{g} / \mathrm{mL})$ ], incubating for $4 \mathrm{~h}$ and measuring fluorescence (ex $550 \mathrm{~nm}, \mathrm{em} 590 \mathrm{~nm}$ ). The results are expressed as percentage reduction in cell growth as compared to untreated control wells. $\mathrm{IC}_{50}$ values were determined using an extended dose range (2-fold compound dilutions, 8-point concentration curve) to a highest concentration of $64 \mu \mathrm{M}$. Tamoxifen was included as the reference drug.

Supplementary Materials: The following are available online, on pages S1-S4: ${ }^{1} \mathrm{H},{ }^{13} \mathrm{C}$ and ${ }^{31} \mathrm{P}$ NMR spectra of compounds GoPI and GoPI-sugar.

Author Contributions: L.F., P.M.L., D.L.W., J.A.S. and E.D.-C. conceived and designed the experiments; L.F., F.C.-N., C.A.B., P.L.d.L., C.F., P.D.Z., S.P. and A.T. performed the experiments; L.F., S.P., P.M.L., F.C.-N., D.L.W., L.M., C.A.B., C.F., J.A.S. and E.D.-C. analyzed the data; L.F., S.P., P.M.L., L.M., D.L.W., J.A.S. and E.D.-C. wrote the paper. All authors have read and agreed to the published version of the manuscript.

Funding: This research was funded by grants of the Laboratoire d'Excellence ParaFrap (grant LabEx ParaFrap ANR-11-LABX-0024 to E.D.-C. and P.L.d.L.'s lab). The Centre National de la Recherche Scientifique (CNRS France, via UMR 7042 to E.D.-C.), and the University of Strasbourg, partly supported this work. P.M.L., L.M. and E.D.-C. (MC members) thank the COST Action CM1307, entitled "Targeted Chemotherapy towards Diseases Caused by Endoparasites" for covering the exchanges and for funding the APC of the special issue of Molecules "COST Action CM1307-Proceedings in Medicinal and Natural Product Chemistry" in open access. L.F. is grateful to the Labex ParaFrap, France, and to Région Alsace for his co-funded CNRS doctoral fellowship (BDI). E.D.-C. and L.F. acknowledge Valérie Deborde for the initiation to the gold(I) phosphole complex chemistry in Strasbourg. Biomphalaria glabrata snails exposed to S. mansoni were provided by the NIAID Schistosomiasis Resource Center of the Biomedical Research Institute (Rockville, MD, USA) through NIH-NIAID Contract HHSN272201700014I for distribution through BEI Resources. Brugia pahangi adult worms were kindly provided by Brenda Beernsten, University of Missouri-Columbia; funding was provided by the Bill and Melinda Gates Foundation to J.A.S.

Conflicts of Interest: The authors declare no conflict of interest.

\section{Abbreviations}

The following abbreviations are used in this manuscript:

DTNB: 5,5'-dithiobis(2-nitrobenzoic acid); GoPI: \{1-phenyl-2,5-di(2-pyridyl)phosphole\}AuCl; GoPI-sugar: 1-thio- $\beta$-D-glucopyranose 2,3,4,6-tetraacetato-S-derivative; GR: glutathione reductase; GSH: glutathione; GSSG: glutathione disulfide; HED: 2-hydroxyethyl disulfide; hTrx: human thioredoxin; ip: intraperitoneal; RA: rheumatoid arthritis; ROS: reactive oxygen species; TGR: thioredoxin-glutathione reductase; TR: trypanothione reductase; Trx: thioredoxin; TrxR: thioredoxin reductase; $\operatorname{TrxS}_{2}$ : thioredoxin disulfide; $\mathrm{TS}_{2}$ : trypanothione disulfide. 


\section{References}

1. Higby, G.J. Gold in medicine: A review of its use in the West before 1900. Gold Bull. 1982, 15, 130-140. [CrossRef] [PubMed]

2. Koch, R. Über bakteriologische Forschung. Dtsch. Med. Wochenstr. 1890, 16, 756-757.

3. Forestier, J. Rheumatoid arthritis and its treatment by gold salts. Lancet 1934, 224, 646-648. [CrossRef]

4. Forestier, J. Rheumatoid arthritis and its treatment by gold salts: The results of six years' experience. J. Lab. Clin. Med. 1935, 20, 827-840.

5. Kean, W.F.; Hart, L.; Buchanan, W.W. Auranofin. Br. J. Rheumatol. 1997, 36, 560-572. [CrossRef] [PubMed]

6. Messori, L.; Marcon, G. Gold complexes in the treatment of rheumatoid arthritis. Met. Ions Biol. Syst. 2004, 41, 279-304. [PubMed]

7. Mirabelli, C.K.; Johnson, R.K.; Hill, D.T.; Faucette, L.F.; Girard, G.R.; Kuo, G.Y.; Sung, C.M.; Crooke, S.T. Correlation of the in vitro cytotoxic and in vivo antitumor activities of gold(I) coordination complexes. J. Med. Chem. 1986, 29, 218-223. [CrossRef]

8. Madeira, J.M.; Gibson, D.L.; Kean, W.F.; Klegeris, A. The biological activity of auranofin: Implications for novel treatment of diseases. Inflammopharmacology 2012, 20, 297-306. [CrossRef]

9. Roder, C.; Thomson, M.J. Auranofin: Repurposing an old drug for a golden new age. Drugs R D 2015, 15, 13-20. [CrossRef]

10. Massai, L.; Messori, L.; Micale, N.; Schirmeister, T.; Maes, L.; Fregona, D.; Cinellu, M.A.; Gabbiani, C. Gold compounds as cysteine protease inhibitors: Perspectives for pharmaceutical application as antiparasitic agents. BioMetals 2017, 30, 313-320. [CrossRef]

11. Gromer, S.; Arscott, L.D.; Williams, C.H., Jr.; Schirmer, R.H.; Becker, K. Human placenta thioredoxin reductase. Isolation of the selenoenzyme, steady state kinetics, and inhibition by therapeutic gold compounds. J. Biol. Chem. 1998, 273, 20096-20101. [CrossRef]

12. Deponte, M.; Urig, S.; Arscott, L.D.; Fritz-Wolf, K.; Réau, R.; Herold-Mende, C.; Koncarevic, S.; Meyer, M.; Davioud-Charvet, E.; Ballou, D.P.; et al. Mechanistic studies on a novel, highly potent gold-phosphole inhibitor of human glutathione reductase. J. Biol. Chem. 2005, 280, 20628-20637. [CrossRef] [PubMed]

13. Urig, S.; Fritz-Wolf, K.; Reau, R.; Herold-Mende, C.; Toth, K.; Davioud-Charvet, E.; Becker, K. Undressing of phosphine gold(I) complexes as irreversible inhibitors of human disulfide reductases. Angew. Chem. Int. Ed. Engl. 2006, 45, 1881-1886. [CrossRef] [PubMed]

14. Viry, E.; Battaglia, E.; Deborde, V.; Müller, T.; Réau, R.; Davioud-Charvet, E.; Bagrel, D. A sugar-modified phosphole gold complex with antiproliferative properties acting as a thioredoxin reductase inhibitor in MCF-7 cells. ChemMedChem 2008, 3, 1667-1670. [CrossRef] [PubMed]

15. Jortzik, E.; Farhadi, M.; Ahmadi, R.; Tóth, K.; Lohr, J.; Helmke, B.M.; Kehr, S.; Unterberg, A.; Ott, I.; Gust, R.; et al. Antiglioma activity of GoPI-sugar, a novel gold(I)-phosphole inhibitor: Chemical synthesis, mechanistic studies, and effectiveness in vivo. Biochim. Biophys. Acta 2014, 1844, 1415-1426. [CrossRef]

16. Fan, C.; Zheng, W.; Fu, X.; Li, X.; Wong, Y.S.; Chen, T. Enhancement of auranofin-induced lung cancer cell apoptosis by selenocystine, a natural inhibitor of TrxR1 in vitro and in vivo. Cell Death Dis. 2014, 5, 1191. [CrossRef]

17. Fiskus, W.; Saba, N.; Shen, M.; Ghias, M.; Liu, J.; Gupta, S.D.; Chauhan, L.; Rao, R.; Gunewardena, S.; Schorno, K.; et al. Auranofin induces lethal oxidative and endoplasmic reticulum stress and exerts potent preclinical activity against chronic lymphocytic leukemia. Cancer Res. 2014, 74, 2520-2532. [CrossRef]

18. Marzano, C.; Gandin, V.; Folda, A.; Scutari, G.; Bindoli, A.; Rigobello, M.P. Inhibition of thioredoxin reductase by auranofin induces apoptosis in cisplatin-resistant human ovarian cancer cells. Free Radic. Biol. Med. 2007, 42, 872-881. [CrossRef]

19. Crooke, S.T.; Mirabelli, C.K. Molecular mechanisms of action of auranofin and other gold complexes as related to their biologic activities. Am. J. Med. 1983, 75, 109-113. [CrossRef]

20. Dessolin, J.; Biot, C.; Davioud-Charvet, E. Bromination studies of the 2,3-dimethylnaphthazarin core allowing easy access to naphthazarin derivatives. J. Org. Chem. 2001, 66, 5616-5619. [CrossRef]

21. Irmler, A.; Bechthold, A.; Davioud-Charvet, E.; Hofmann, V.; Réau, R.; Gromer, S.; Schirmer, R.H.; Becker, K. Disulfide reductases-current developments. In Flavins and Flavoproteins 2002; Chapman, S.K., Perham, R.N., Scrutton, N.S., Eds.; Agency for Scientific Publications: Berlin, Germany, 2002; pp. 803-815. 
22. Millet, R.; Urig, S.; Jacob, J.; Amtmann, E.; Moulinoux, J.P.; Gromer, S.; Becker, K.; Davioud-Charvet, E. Synthesis of 5-nitro-2-furancarbohydrazides and their cis-diamminedichloroplatinum complexes as bitopic and irreversible human thioredoxin reductase inhibitors. J. Med. Chem. 2005, 48, 7024-7039. [CrossRef] [PubMed]

23. Davioud-Charvet, E.; McLeish, M.J.; Veine, D.M.; Giegel, D.; Arscott, L.D.; Andricopulo, A.D.; Becker, K.; Müller, S.; Schirmer, R.H.; Williams, C.H., Jr.; et al. Mechanism-based inactivation of thioredoxin reductase from Plasmodium falciparum by Mannich bases. Implication for cytotoxicity. Biochemistry 2003, 42, 13319-13330. [CrossRef] [PubMed]

24. Kuntz, A.N.; Davioud-Charvet, E.; Sayed, A.A.; Califf, L.L.; Dessolin, J.; Arnér, E.S.; Williams, D.L. Thioredoxin glutathione reductase from Schistosoma mansoni: An essential parasite enzyme and a key drug target. PLoS Med. 2007, 4, e206, Erratum in: PLoS Med. 2007, 4, e264.

25. Andricopulo, A.D.; Akoachere, M.B.; Krogh, R.; Nickel, C.; McLeish, M.J.; Kenyon, G.L.; Arscott, L.D.; Williams, C.H., Jr.; Davioud-Charvet, E.; Becker, K. Specific inhibitors of Plasmodium falciparum thioredoxin reductase as potential antimalarial agents. Bioorg. Med. Chem. Lett. 2006, 16, 2283-2922. [CrossRef]

26. Abrams, M.J.; Murrer, B.A. Metal compounds in therapy and diagnosis. Science 1993, 261, 725-730. [CrossRef]

27. Angelucci, F.; Sayed, A.A.; Williams, D.L.; Boumis, G.; Brunori, M.; Dimastrogiovanni, D.; Miele, A.E.; Pauly, F.; Bellelli, A. Inhibition of Schistosoma mansoni thioredoxin-glutathione reductase by auranofin: Structural and kinetic aspects. J. Biol. Chem. 2009, 284, 28977-28985. [CrossRef]

28. Roberts, J.R.; Xiao, J.; Schliesman, B.; Parsons, D.J.; Shaw, C.F., 3rd. Kinetics and Mechanism of the Reaction between Serum Albumin and Auranofin (and Its Isopropyl Analogue) In Vitro. Inorg. Chem. 1996, 35, 424-433. [CrossRef]

29. Zou, J.; Taylor, P.; Dornan, J.; Robinson, S.P.; Walkinshaw, M.D.; Sadler, P.J. First crystal structure of a medicinally relevant gold protein complex: Unexpected binding of $\left[\mathrm{Au}\left(\mathrm{PEt}_{3}\right)\right](+)$ to histidine. Angew. Chem. Int. Ed. 2000, 39, 2931-2934. [CrossRef]

30. Da Silva, M.T.; Silva-Jardim, I.; Portapilla, G.B.; de Lima, G.M.; Costa, F.C.; Anibal, F.F.; Thiemann, O.H. In vivo and in vitro auranofin activity against Trypanosoma cruzi: Possible new uses for an old drug. Exp. Parasitol. 2016, 166, 189-193. [CrossRef]

31. Ilari, A.; Baiocco, P.; Messori, L.; Fiorillo, A.; Boffi, A.; Gramiccia, M.; Di Muccio, T.; Colotti, G. A goldcontaining drug against parasitic polyamine metabolism: The X-ray structure of trypanothione reductase from Leishmania infantum in complex with auranofin reveals a dual mechanism of enzyme inhibition. Amino Acids 2012, 42, 803-811. [CrossRef]

32. Sannella, A.R.; Casini, A.; Gabbiani, C.; Messori, L.; Bilia, A.R.; Vincieri, F.F.; Majori, G.; Severini, C. New uses for old drugs. Auranofin, a clinically established antiarthritic metallodrug, exhibits potent antimalarial effects in vitro: Mechanistic and pharmacological implications. FEBS Lett. 2008, 582, 844-847. [CrossRef] [PubMed]

33. Tejman-Yarden, N.; Miyamoto, Y.; Leitsch, D.; Santini, J.; Debnath, A.; Gut, J.; McKerrow, J.H.; Reed, S.L.; Eckmann, L. A reprofiled drug, auranofin, is effective against metronidazole-resistant Giardia lamblia. Antimicrob. Agents Chemother. 2013, 57, 2029-2035. [CrossRef]

34. Bonilla, M.; Denicola, A.; Novoselov, S.V.; Turanov, A.A.; Protasio, A.; Izmendi, D.; Gladyshev, V.N.; Salinas, G. Platyhelminth mitochondrial and cytosolic redox homeostasis is controlled by a single thioredoxin glutathione reductase and dependent on selenium and glutathione. J. Biol. Chem. 2008, 283, 17898-17907. [CrossRef] [PubMed]

35. Debnath, A.; Parsonage, D.; Andrade, R.M.; He, C.; Cobo, E.R.; Hirata, K.; Chen, S.; García-Rivera, G.; Orozco, E.; Martínez, M.B.; et al. A high-throughput drug screen for Entamoeba histolytica identifies a new lead and target. Nat. Med. 2012, 18, 956-960. [CrossRef] [PubMed]

36. Bulman, C.A.; Bidlow, C.M.; Lustigman, S.; Cho-Ngwa, F.; Williams, D.; Rascón, A.A., Jr.; Tricoche, N.; Samje, M.; Bell, A.; Suzuki, B.; et al. Repurposing auranofin as a lead candidate for treatment of lymphatic filariasis and onchocerciasis. PLoS Negl. Trop. Dis. 2015, 9, e0003534. [CrossRef] [PubMed]

37. Sonogashira, K. Development of $\mathrm{Pd}-\mathrm{Cu}$ catalyzed cross-coupling of terminal acetylenes with $\mathrm{sp}^{2}$-carbon halides. J. Organomet. Chem. 2002, 53, 46-49. [CrossRef]

38. Aranda Perez, A.I.; Biet, T.; Graule, S.; Agou, T.; Lescop, C.; Branda, N.R.; Crassous, J.; Réau, R. Chiral and extended $\pi$-conjugated bis(2-pyridyl)phospholes as assembling N,P,N pincers for coordination-driven synthesis of supramolecular [2,2]paracyclophane analogues. Chemistry 2011, 17, 1337-1351. [CrossRef] 
39. Hay, C.; Hissler, M.; Fischmeister, C.; Rault-Berthelot, J.; Toupet, L.; Nyulászi, L.; Réau, R. Phospholecontaining pi-conjugated systems: From model molecules to polymer films on electrodes. Chemistry 2001, 7, 4222-4236. [CrossRef]

40. Yan, X.; Xi, C. Conversion of zirconacyclopentadienes into metalloles: Fagan-Nugent reaction and beyond, Acc. Chem. Res. 2015, 48, 935-946. [CrossRef]

41. King, C.H. Parasites and poverty: The case of schistosomiasis. Acta Trop. 2010, 113, 95-104. [CrossRef]

42. Bergquist, R.; Elmorshedy, H. Artemether and Praziquantel: Origin, Mode of Action, Impact, and Suggested Application for Effective Control of Human Schistosomiasis. Trop. Med. Infect. Dis. 2018, 3, 125. [CrossRef] [PubMed]

43. Alger, H.M.; Williams, D.L. The disulfide redox system of Schistosoma mansoni and the importance of a multifunctional enzyme, thioredoxin glutathione reductase. Mol. Biochem. Parasitol. 2002, 121, 129-139. [CrossRef]

44. Williams, D.L.; Bonilla, M.; Gladyshev, V.N.; Salinas, G. Thioredoxin glutathione reductase-dependent redox networks in platyhelminth parasites. Antioxid. Redox Signal. 2013, 19, 735-745. [CrossRef]

45. Bonilla, M.; Denicola, A.; Marino, S.M.; Gladyshev, V.N.; Salinas, G. Linked thioredoxin-glutathione systems in platyhelminth parasites: Alternative pathways for glutathione reduction and deglutathionylation. J. Biol. Chem. 2011, 286, 4959-4967. [CrossRef]

46. Prast-Nielsen, S.; Huang, H.-H.; Williams, D.L. Thioredoxin glutathione reductase: Its role in redox biology and potential as a target for drugs against neglected diseases. Biochim. Biophys. Acta 2011, 1810, 1262-1271. [CrossRef]

47. Angelucci, F.; Dimastrogiovanni, D.; Boumis, G.; Brunori, M.; Miele, A.E.; Saccoccia, F.; Bellelli, A. Mapping the catalytic cycle of Schistosoma mansoni thioredoxin glutathione reductase by X-ray crystallography. J. Biol. Chem. 2010, 285, 32557-32567. [CrossRef] [PubMed]

48. Huang, H.-H.; Day, L.; Cass, C.L.; Ballou, D.P.; Williams, C.H., Jr.; Williams, D.L. Investigations of the catalytic mechanism of thioredoxin glutathione reductase from Schistosoma mansoni. Biochemistry 2011, 50, 5870-5882. [CrossRef]

49. Salinas, G.; Gao, W.; Wang, Y.; Bonilla, M.; Yu, L.; Novikov, A.; Virginio, V.G.; Ferreira, H.B.; Vieites, M.; Gladyshev, V.N.; et al. The Enzymatic and Structural Basis for Inhibition of Echinococcus granulosus Thioredoxin Glutathione Reductase by Gold(I). Antioxid. Redox Signal. 2017, 27, 1491-1504. [CrossRef]

50. Martínez-González, J.J.; Guevara-Flores, A.; Rendón, J.L.; Arenal, I.P.D. Auranofin-induced oxidative stress causes redistribution of the glutathione pool in Taenia crassiceps cysticerci. Mol. Biochem. Parasitol. 2015, 27, 16-25. [CrossRef]

51. Martínez-González, J.J.; Guevara-Flores, A.; Alvarez, G.; Rendón-Gómez, J.L.; Del Arenal, I.P. In vitro killing action of auranofin on Taenia crassiceps metacestode (cysticerci) and inactivation of thioredoxin-glutathione reductase (TGR). Parasitol Res. 2010, 107, 227-231. [CrossRef]

52. Rigobello, M.P.; Messori, L.; Marcon, G.; Agostina Cinellu, M.; Bragadin, M.; Folda, A.; Scutari, G.; Bindoli, A. Gold complexes inhibit mitochondrial thioredoxin reductase: Consequences on mitochondrial functions. J. Inorg. Biochem. 2004, 98, 1634-1641. [CrossRef]

53. Capparelli, E.V.; Bricker-Ford, R.; Rogers, M.J.; McKerrow, J.H.; Reed, S.L. Phase I Clinical Trial Results of Auranofin, a Novel Antiparasitic Agent. Antimicrob. Agents Chemother. 2016, 61, e01947-e02016. [CrossRef] [PubMed]

54. Lombardo, F.C.; Pasche, V.; Panic, G.; Endriss, Y.; Keiser, J. Life cycle maintenance and drug-sensitivity assays for early drug discovery in Schistosoma mansoni. Nat. Protoc. 2019, 14, 461-481. [CrossRef]

55. Marcellino, C.; Gut, J.; Lim, K.C.; Singh, R.; McKerrow, J.; Sakanari, J. WormAssay: A novel computer application for whole plate screening of macroscopic parasites. PLoS Negl. Trop. Dis. 2012, 6, e1494. [CrossRef]

56. Gardon, J.; Gardon-Wendel, N.; Demanga, N.; Kamgno, J.; Chippaux, J.P.; Boussinesq, M. Serious reactions after mass treatment of onchocerciasis with ivermectin in an area endemic for Loa loa infection. Lancet 1997, 350, 18-22. [CrossRef]

57. Boussinesq, M.; Gardon, J.; Gardon-Wendel, N.; Chippaux, J.P. Clinical picture, epidemiology and outcome of Loa-associated serious adverse events related to mass ivermectin treatment of onchocerciasis in Cameroon. Filaria J. 2003, 2 (Suppl 1), S4. [CrossRef]

58. Fairlamb, A.H.; Cerami, A. Metabolism and functions of trypanothione in the Kinetoplastida. Annu. Rev. Microbiol. 1992, 46, 695-729. [CrossRef] 
59. Krieger, S.; Schwarz, W.; Ariyanayagam, M.R.; Fairlamb, A.H.; Krauth-Siegel, R.L.; Clayton, C. Trypanosomes lacking trypanothione reductase are avirulent and show increased sensitivity to oxidative stress. Mol. Microbiol. 2000, 35, 542-552. [CrossRef] [PubMed]

60. Gendron, T.; Lanfranchi, D.A.; Davioud-Charvet, E. Redox-active agents in reactions involving the trypanothione/trypanothione reductase-based system to fight kinetoplastidal parasites. In Drug Discovery in Infectious Diseases; Selzer, P.M., Ed.; Wiley-VCH Verlag GmbH \& Co. KGaA: Weinheim, Germany, 2013; Volume 4, pp. 405-428.

61. Lee, B.; Bauer, H.; Melchers, J.; Ruppert, T.; Rattray, L.; Yardley, V.; Davioud-Charvet, E.; Krauth-Siegel, R.L. Irreversible inactivation of trypanothione reductase by unsaturated Mannich bases: A divinyl ketone as key intermediate. J. Med. Chem. 2005, 48, 7400-7410. [CrossRef]

62. Lazarin-Bidóia, D.; Desoti, V.C.; Martins, S.C.; Ribeiro, F.M.; Ud Din, Z.; Rodrigues-Filho, E.; Ueda-Nakamura, T.; Nakamura, C.V.; de Oliveira Silva, S. Dibenzylideneacetones Are Potent Trypanocidal Compounds That Affect the Trypanosoma cruzi Redox System. Antimicrob. Agents Chemother. 2015, 60, 890-903. [CrossRef]

63. Cheikh-Ali, Z.; Caron, J.; Cojean, S.; Bories, C.; Couvreur, P.; Loiseau, P.M.; Desmaële, D.; Poupon, E.; Champy, P. "Squalenoylcurcumin" nanoassemblies as water-dispersible drug candidates with antileishmanial activity. Chem. Med. Chem. 2015, 10, 411-418. [CrossRef] [PubMed]

64. Fairlamb, A.H.; Henderson, G.B.; Cerami, A. Trypanothione is the primary target for arsenical drugs against African trypanosomes. Proc. Natl. Acad. Sci. USA 1989, 86, 2607-2611. [CrossRef]

65. Wyllie, S.; Cunningham, M.L.; Fairlamb, A.H. Dual action of antimonial drugs on thiol redox metabolism in the human pathogen Leishmania donovani. J. Biol. Chem. 2004, 279, 39925-39932. [CrossRef] [PubMed]

66. Sharlow, E.R.; Leimgruber, S.; Murray, S.; Lira, A.; Sciotti, R.J.; Hickman, M.; Hudson, T.; Leed, S.; Caridha, T.; Barrios, A.M.; et al. Auranofin is an apoptosis-stimulating agent with in vitro and in vivo anti-leishmanial activity. ACS Chem. Biol. 2014, 9, 663-672. [CrossRef]

67. Ondarza, R.N.; Iturbe, A.; Hernández, E.; Hurtado, G. Thiol compounds from a free-living pathogenic opportunistic amoeba, Acanthamoeba polyphaga. Biotechnol. Appl. Biochem. 2002, 36, 195-204. [CrossRef]

68. Ondarza, R.N.; Iturbe, A.; Hernández, E. The effects by neuroleptics, antimycotics and antibiotics on disulfide reducing enzymes from the human pathogens Acanthamoeba polyphaga and Naegleria fowleri. Exp. Parasitol. 2007, 115, 41-47. [CrossRef] [PubMed]

69. Taravaud, A.; Loiseau, P.M.; Pomel, S. In vitro evaluation of antimicrobial agents on Acanthamoeba sp. and evidence of a natural resilience to amphotericin B. Int. J. Parasitol. Drugs Drug Resist. 2017, 7, 328-336. [CrossRef]

70. Chaussepied, M.; Langsley, G. Theileria transformation of bovine leukocytes: A parasite model for the study of lymphoproliferation. Res. Immunol. 1996, 147, 127-138. [CrossRef]

71. Dobbelaere, D.; Heussler, V. Transformation of leukocytes by Theileria parva and T. annulata. Annu. Rev. Microbiol. 1999, 53, 1-42. [CrossRef] [PubMed]

72. Darghouth, M.A. Review on the experience with live attenuated vaccines against tropical theileriosis in Tunisia: Considerations for the present and implications for the future. Vaccine 2008, 26, G4-G10. [CrossRef]

73. Baylis, H.A.; Megson, A.; Hall, R. Infection with Theileria annulata induces expression of matrix metalloproteinase 9 and transcription factor AP-1 in bovine leucocytes. Mol. Biochem. Parasitol. 1995, 69, 211-222. [CrossRef]

74. Hall, R.; Ilhan, T.; Kirvar, E.; Wilkie, G.; Preston, P.M.; Darghouth, M.; Somerville, R.; Adamson, R. Mechanism(s) of attenuation of Theileria annulata vaccine cell lines. Trop. Med. Int. Health 1999, 4, A78-A84. [CrossRef] [PubMed]

75. Shiels, B.; Langsley, G.; Weir, W.; Pain, A.; McKellar, S.; Dobbelaere, D. Alteration of host cell phenotype by Theileria annulata and Theileria parva: Mining for manipulators in the parasite genomes. Int. J. Parasitol. 2006, 36, 9-21. [CrossRef] [PubMed]

76. Chaussepied, M.; Janski, N.; Baumgartner, M.; Lizundia, R.; Jensen, K.; Weir, W.; Shiels, B.R.; Weitzman, J.B.; Glass, E.J.; Werling, D.; et al. TGF-b2 induction regulates invasiveness of Theileria-transformed leukocytes and disease susceptibility. PLoS Pathog. 2010, 6, e1001197. [CrossRef]

77. Haidar, M.; Whitworth, J.; Noé, G.; Liu, W.; Vidal, M.; Langsley, G. TGF- $\beta 2$ induces Grb2 to recruit PI3-K to TGF-RII that activates JNK/AP-1-signaling and augments invasiveness of Theileria-transformed macrophages. Sci. Rep. 2015, 5, 15688. [CrossRef] [PubMed] 
78. Haidar, M.; Echebli, N.; Ding, Y.; Kamau, E.; Langsley, G. Transforming growth factor $\beta 2$ promotes transcription of COX2 and EP4, leading to a prostaglandin E2-driven autostimulatory loop that enhances virulence of Theileria annulata-transformed macrophages. Infect. Immun. 2015, 83, 1869-1880. [CrossRef]

79. Dessauge, F.; Lizundia, R.; Baumgartner, M.; Chaussepied, M.; Langsley, G. Taking the Myc is bad for Theileria. Trends Parasitol. 2005, 21, 377-385. [CrossRef]

80. Dessauge, F.; Hilaly, S.; Baumgartner, M.; Blumen, B.; Werling, D.; Langsley, G. c-Myc activation by Theileria parasites promotes survival of infected B-lymphocytes. Oncogene 2005, 24, 1075-1083. [CrossRef]

81. Heussler, V.T.; Rottenberg, S.; Schwab, R.; Küenzi, P.; Fernandez, P.C.; McKellar, S.; Shiels, B.; Chen, Z.J.; Orth, K.; Wallach, D.; et al. Hijacking of host cell IKK signalosomes by the transforming parasite Theileria. Science 2002, 298, 1033-1036. [CrossRef]

82. Lizundia, R.; Chaussepied, M.; Naissant, B.; Masse, G.X.; Quevillon, E.; Michel, F.; Monier, S.; Weitzman, J.-B.; Langsley, G. The JNK/AP-1 pathway upregulates expression of the recycling endosome rab11a gene in B cells transformed by Theileria. Cell Microbiol. 2007, 9, 1936-1945. [CrossRef]

83. Adamson, R.; Logan, M.; Kinnaird, J.; Langsley, G.; Hall, R. Loss of matrix metalloproteinase 9 activity in Theileria annulata-attenuated cells is at the transcriptional level and is associated with differentially expressed AP-1 species. Mol. Biochem. Parasitol. 2000, 106, 51-61. [CrossRef]

84. Chaussepied, M.; Lallemand, D.; Moreau, M.F.; Adamson, R.; Hall, R.; Langsley, G. Upregulation of Jun and Fos family members and permanent JNK activity lead to constitutive AP-1 activation in Theileria-transformed leukocytes. Mol. Biochem. Parasitol. 1998, 94, 215-226. [CrossRef]

85. Metheni, M.; Echebli, N.; Chaussepied, M.; Ransy, C.; Chéreau, C.; Jensen, K.; Glass, E.; Batteux, F.; Bouillaud, F.; Langsley, G. The level of $\mathrm{H}_{2} \mathrm{O}_{2}$ type oxidative stress regulates virulence of Theileria-transformed leukocytes. Cell Microbiol. 2014, 16, 269-279. [CrossRef] [PubMed]

86. Lanza, J.S.; Pomel, S.; Loiseau, P.M.; Frézard, F. Recent advances in amphotericin B delivery strategies for the treatment of leishmaniases. Expert Opin. Drug Deliv. 2019, 16, 1063-1079. [CrossRef]

87. Sundar, S.; Chakravarty, J.; Agarwal, D.; Rai, M.; Murray, H.W. Single-dose liposomal amphotericin B for visceral leishmaniasis in India. N. Engl. J. Med. 2010, 362, 504-512. [CrossRef]

88. Gao, N.; Xing, C.; Wang, H.; Feng, L.; Zeng, X.; Mei, L.; Peng, Z. pH-Responsive Dual Drug-Loaded Nanocarriers Based on Poly (2-Ethyl-2-Oxazoline) Modified Black Phosphorus Nanosheets for Cancer Chemo/Photothermal Therapy. Front Pharmacol. 2019, 10, 1-14. [CrossRef]

89. Tucker, M.S.; Karunaratne, L.B.; Lewis, F.A.; Freitas, T.C.; Liang, Y.-S. Schistosomiasis. Curr. Protoc. Immunol. 2013, 103, 19.1.1-19.1.58. [CrossRef]

90. Hirumi, H.; Hirumi, K. Continuous cultivation of Trypanosoma brucei blood stream forms in a medium containing a low concentration of serum protein without feeder cell layers. J. Parasitol. 1989, 75, 985-989. [CrossRef]

91. Räz, B.; Iten, M.; Grether-Bühler, Y.; Kaminsky, R.; Brun, R. The Alamar Blue assay to determine drug sensitivity of African trypanosomes (T.b. rhodesiense and T.b. gambiense) in vitro. Acta Trop. 1997, 68, 139-147. [CrossRef]

92. Buckner, F.S.; Verlinde, C.L.; La Flamme, A.C.; Van Voorhis, W.C. Efficient technique for screening drugs for activity against Trypanosoma cruzi using parasites expressing $\beta$-galactosidase. Antimicrob. Agents Chemother. 1996, 40, 2592-2597. [CrossRef]

93. Sager, H.; Davis, W.C.; Dobbelaere, D.A.; Jungi, T.W. Macrophage-parasite relationship in theileriosis. Reversible phenotypic and functional dedifferentiation of macrophages infected with Theileria annulata. J. Leukoc. Biol. 1997, 61, 459-468. [CrossRef]

94. Mao, W.; Daligaux, P.; Lazar, N.; Ha-Duong, T.; Cavé, C.; van Tilbeurgh, H.; Loiseau, P.M.; Pomel, S. Biochemical analysis of leishmanial and human GDP-Mannose Pyrophosphorylases and selection of inhibitors as new leads. Sci. Rep. 2017, 7, 751. [CrossRef] [PubMed]

Sample Availability: Samples of the compounds GoPI, GoPI-sugar (LF-028) and of auranofin are available from the authors.

Publisher's Note: MDPI stays neutral with regard to jurisdictional claims in published maps and institutional affiliations. 